\title{
Numerical Simulation of Groundwater Withdrawal within the Mercury Valley Administrative Groundwater Basin, Nevada
}

\author{
Prepared by
}

A. Brooke Gilliam, Rosemary W.H. Carroll, Greg Pohll and Ronald L. Hershey

\author{
submitted to \\ Nevada Site Office \\ National Nuclear Security Administration \\ U.S. Department of Energy \\ Las Vegas, Nevada
}

January 2006

Publication No. 45214 
Reference herein to any specific commercial product, process, or service by trade name, trademark, manufacturer, or otherwise, does not necessarily constitute or imply its endorsement, recommendation, or favoring by the United States Government or any agency thereof or its contractors or subcontractors. The views and opinions of authors expressed herein do not necessarily state or reflect those of the United States Government or any agency thereof.

Available for sale to the public, in paper, from:

U.S. Department of Commerce

National Technical Information Service

5285 Port Royal Rd.

Springfield, VA 22161

phone: 800.553.6847

fax: 703.605.6900

email: order@ntis.gov

online ordering: http://www.ntis.gov/ordering.htm

Available electronically at http://www.doe.gov/bridge

Available for a processing fee to the U.S. Department of Energy and its contractors, in paper, from: U.S. Department of Energy

Office of Scientific and Technical Information

P.O. Box 62

Oak Ridge, TN 37831-0062

phone: 865.576.8401

fax: 865.576.5728

email: reports@adonis.osti.gov 


\title{
Numerical Simulation of Groundwater Withdrawal within the Mercury Valley Administrative Groundwater Basin, Nevada
}

\author{
Prepared by \\ A. Brooke Gilliam, Rosemary W.H. Carroll, Greg Pohll and Ronald L. Hershey \\ Division of Hydrologic Sciences \\ Desert Research Institute \\ Nevada System of Higher Education
}

Publication No. 45214

\author{
Submitted to \\ Nevada Site Office \\ National Nuclear Security Administration \\ U.S. Department of Energy \\ Las Vegas, Nevada
}

January 2006

The work upon which this report is based was supported by the U.S. Department of Energy under Contract \#DE-AC52-00NV13609. Approved for public release; further dissemination unlimited. 
THIS PAGE INTENTIONALLY LEFT BLANK 


\begin{abstract}
A detailed, transient, three-dimensional, finite-difference groundwater flow model was created for the Mercury Valley Administrative Groundwater Basin (MVB). The MVB is a distinct groundwater basin as defined by the State of Nevada and is located partially within the boundary of the Nevada Test Site. This basin is being studied as a potential location for new industrial facilities and therefore would be subject to Nevada water-use limitations. The MVB model was used to estimate the volume of water that could be withdrawn from Mercury Valley without inducing laterally or vertically extensive water-table effects. In each model simulation, water-table drawdown was limited to a maximum of $0.5 \mathrm{~m}$ at the boundary of the basin and held within the screened interval of the well. Water withdrawal from Nevada groundwater basins is also limited to the State-defined perennial yield for that area. The perennial yield for the MVB is 27,036 $\mathrm{m}^{3} /$ day.
\end{abstract}

The one existing water-supply well in Mercury Valley is capable of sustaining significantly higher withdrawal rates than it currently produces. Simulations showed this single well could produce 50 percent of the basin's perennial yield with limited water-table drawdown. Pumping from six hypothetical water-supply wells was also simulated. Each hypothetical well was placed in an area of high hydraulic conductivity and far from the basin's boundaries. Each of these wells was capable of producing at least 50 percent of the basin's perennial yield. One of the hypothetical wells could simulate 100 percent of the perennial yield while staying within drawdown limitations. Multi-well simulations where two or more water-supply wells were simultaneously pumping were also conducted. These simulations almost always resulted in very limited lateral and vertical drawdown and produced 100 percent of Mercury Valley’s perennial yield.

A water-budget analysis was also conducted for each of the various stress simulations. Each of the stress scenarios was compared to a baseline scenario where existing water-supply wells in the model domain were pumped at 2003-2004 average pumping rates. Water-budget analyses showed increased flow from the constant-head boundaries on the north, east, and west sides of the model. Flow to the southern, head-dependent boundary and to springs in the Ash Meadows area remained unchanged. 
THIS PAGE INTENTIONALLY LEFT BLANK 


\section{CONTENTS}

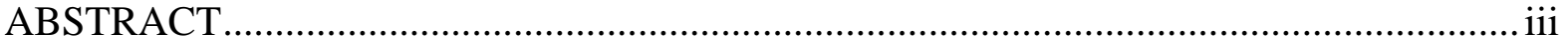

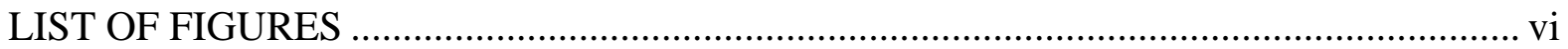

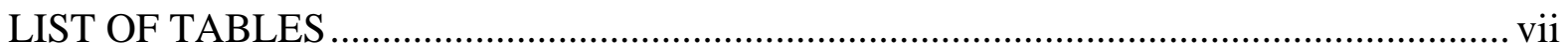

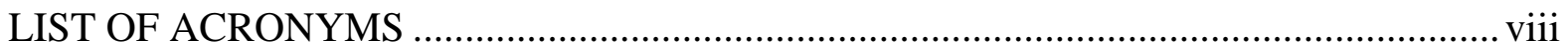

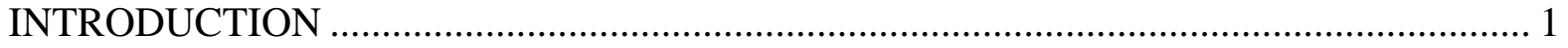

TECHNICAL APPROACH OVERVIEW …………….................................................. 1

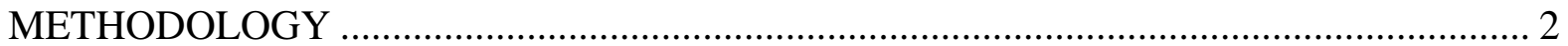

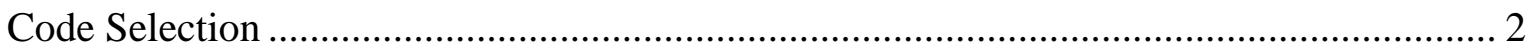

Groundwater Flow Equation....................................................................................... 2

Steady-state Model................................................................................................... 3

MVB Model Domain ........................................................................................... 3

Model Assumptions .................................................................................................. 4

Hydrostratigraphic Units and Layer Classification....................................................... 5

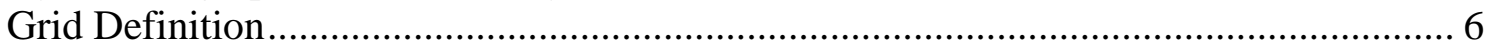

Hydraulic Conductivity .......................................................................................... 7

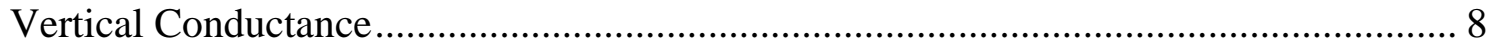

Boundary Conditions ……………………............................................................. 9

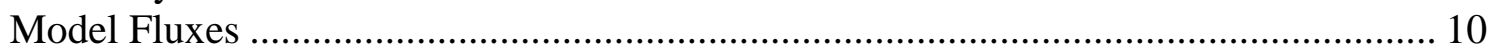

Transient Model Development ……………………………........................................... 11

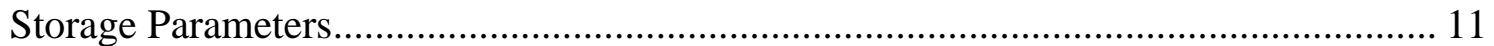

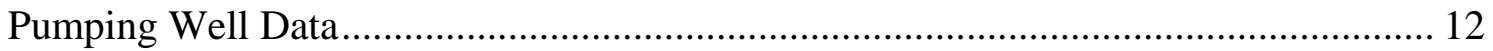

Pumping Scenarios....................................................................................................... 13

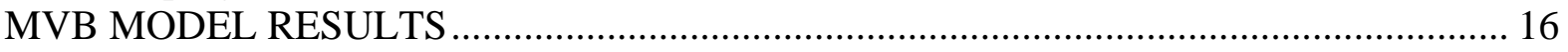

Steady-state Model Results..................................................................................... 16

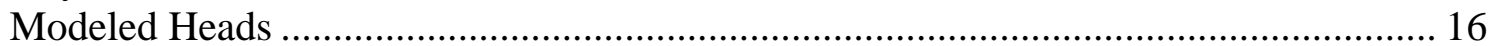

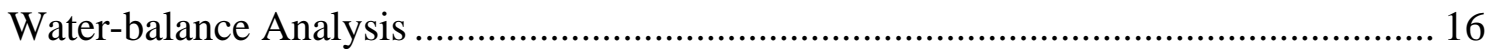

Transient Model Results ........................................................................................ 17

Transient Model Calibration .................................................................................... 17

Transient Model Verification................................................................................... 17

Baseline Stress Scenario ........................................................................................... 19

Mercury Valley Maximum Stress Scenario.................................................................... 20

Hypothetical Well Optimization Simulations ................................................................... 22

Thiem Drawdown Corrections................................................................................. 34

Transient Results Summary …………………….................................................... 35

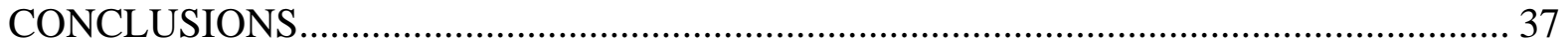

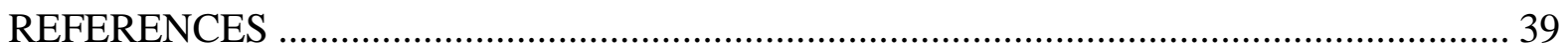




\section{LIST OF FIGURES}

1. Map showing the MVB and UGTA model domains.

2. Map showing expanded MVB model boundary encompassing five water-supply wells and springs in the Ash Meadows area..

3. Graph comparing hydraulic conductivity of three classes of HSUs to depth below land surface.

4. Map of the MVB model domain showing spring locations and head-dependent flux boundary locations.

5. Location of existing water-supply wells: Army \#1 Water Well, Water Well 5B, Water Well 5C, J-12 Water Well, and J-13 Water Well.

6. Horizontal hydraulic conductivity field for model layer 8. Contour interval is $20 \mathrm{~m}$........15

7. A graph for each existing water-supply well that had a USGS water-level dataset. ..........18

8. Water-level elevation during baseline stress scenario for the five model cells containing existing wells in the MVB model domain.

9. The lateral extent of drawdown in excess of baseline scenario drawdown (model layer 8) in Mercury Valley for the maximum stress scenario with 50 percent of the estimated perennial yield withdrawn from Army \#1 Water Well.

10. Drawdown within the model cell and recovery of head with respect to time plotted for the seven single well maximum stress pumping scenarios.

11. The lateral extent of drawdown for 40 years, model layer 8, in Mercury Valley with 40 percent of the estimated perennial yield withdrawn from hypothetical Well A...........22

12. The lateral extent of drawdown for 40 years, model layer 8, in Mercury Valley with 50 percent of the estimated perennial yield withdrawn from hypothetical Well A...........23

13. The lateral extent of drawdown for 40 years, model layer 8, in Mercury Valley with 90 percent of the estimated perennial yield withdrawn from hypothetical Well B.

14. The lateral extent of drawdown for 40 years, model layer 8, in Mercury Valley with 100 percent of the estimated perennial yield withdrawn from hypothetical Well B. ........25

15. The lateral extent of drawdown for 40 years, model layer 8, in Mercury Valley with 70 percent of the estimated perennial yield withdrawn from hypothetical Well C...........26

16. The lateral extent of drawdown for 40 years, model layer 8, in Mercury Valley with 80 percent of the estimated perennial yield withdrawn from hypothetical Well D...........27

17. The lateral extent of drawdown for 40 years, model layer 8, in Mercury Valley with 50 percent of the estimated perennial yield withdrawn from hypothetical Well E.

18. The lateral extent of drawdown after 40 years, model layer 8, in Mercury Valley with 60 percent of the estimated perennial yield withdrawn from hypothetical Well F.

19. The lateral extent of drawdown after 40 years, model layer 8, in Mercury Valley with 70 percent of the estimated perennial yield withdrawn from hypothetical Well F.

20. The lateral extent of drawdown after 40 years, model layer 8, in Mercury Valley with hypothetical wells A through F collectively pumping perennial yield.

21. Drawdown and recovery with respect to time plotted for theoretical wells A through F, each simultaneously pumping one-sixth of the perennial yield. 


\section{LIST OF TABLES}

1. Comparison of UGTA and MVB model layer elevations and thicknesses.

2. Summary of location, slotted/open interval elevation, static water-level elevation, baseline pumping rate, and horizontal hydraulic conductivity for existing water-supply wells in the MVB flow model.

3. Summary of location, slotted/open interval elevation, and horizontal hydraulic conductivity value for the six hypothetical water-supply wells in the MVB model.

4. Flux comparison of MVB model and a corresponding volume of the UGTA model domain.

5. Volumetric water-budget summaries and percentage change comparison for the MVB flow model between the steady-state scenario and existing Army \#1 Water Well shown.

6. Volumetric water-budget summaries and percentage change comparison for the MVB flow model between the steady-state scenario and hypothetical Well A shown ( $\left.\mathrm{m}^{3} / \mathrm{day}\right)$ pumped at 50 percent of the estimated perennial yield.

7. Volumetric water-budget summaries and percentage change comparison for the MVB flow model between the steady-state scenario and hypothetical Well B shown.

8. Volumetric water-budget summaries and percentage change comparison for the MVB flow model between the steady-state scenario and hypothetical water Well C shown. ....27

9. Volumetric water-budget summaries and percentage change comparison for the MVB flow model between the steady-state scenario and hypothetical water Well D shown.....28

10. Volumetric water-budget summaries and percentage change comparison for the MVB flow model between the steady-state scenario and hypothetical water Well E shown......29

11. Volumetric water-budget summaries and percentage change comparison for the MVB flow model between the steady-state scenario and hypothetical water Well F shown......31

12. Volumetric water-budget summaries and percentage change comparison for the MVB flow model between the steady-state scenario and the six hypothetical well pumping scenario shown.

13. The head at each well before stress simulations began, the head calculated for the cell by MODFLOW where any drawdown is averaged across the cell area, the head calculated using the Thiem Equation to approximate the drawdown in the well bore, and corrected drawdown measured as the head difference at the well at baseline conditions and after the stress simulations. 


\section{LIST OF ACRONYMS}

DOE U.S. Department of Energy

HSU hydrostratigraphic unit

NTS Nevada Test Site

MVB Mercury Valley Administrative Groundwater Basin

NDWR Nevada Division of Water Resources

UGTA Underground Test Area

USGS U.S. Geological Survey 


\section{INTRODUCTION}

The U.S. Department of Energy (DOE), National Nuclear Security Administration Nevada Site Office is currently evaluating alternative uses of the Nevada Test Site (NTS). Some of the possible alternative uses may require large amounts of water for construction and/or operation. The only abundant source of water at the NTS is groundwater. Presently, all groundwater withdrawals for defense programs are exempt from the State of Nevada permitting process. However, other uses of groundwater may be subject to State permitting. Before any new uses of the NTS can be pursued, the availability of groundwater resources for those uses must be considered. This report describes the potential development of groundwater resources within the Mercury Valley Administrative Groundwater Basin (MVB).

\section{TECHNICAL APPROACH OVERVIEW}

The state of Nevada is divided into 232 Administrative Groundwater Basins (Nevada Division of Water Resources (NDWR), Department of Conservation and Natural Resources [www.water.nv.gov, April 2003]). A groundwater basin is a discrete hydrologic unit for water planning and management purposes. This report examines the effect of groundwater withdrawal from the MVB (groundwater basin 225), which lies partially within the NTS, by using a three-dimensional transient numerical groundwater flow model. Future groundwater withdrawals from the MVB may be subject to the NDWR-permitting process. The Statedefined perennial yield of Mercury Valley dictates the maximum pumpage from within the valley, but this study will look at maximum possible withdrawals limited by water-table drawdown. These limitations are 1) lateral drawdown may not exceed $0.5 \mathrm{~m}$ at MVB boundaries, and 2) the water table at the well must not drop below the top of the screened interval of the well (Carroll et al., 2003). These limits were chosen because if the perennial yield was pumped from a single site from within the groundwater basin, large vertical or lateral drawdown could disturb the regional flow system. The report builds on a preliminary transient numerical simulation of Mercury Valley and four other groundwater basins by Carroll et al. (2003), which pointed to the possible development potential of the valley.

A recently modified version of the Underground Test Area (UGTA) Program's steady-state regional groundwater model (DOE, 1997) that included changes to the Frenchman Flat area (Richard Waddell, GeoTrans Inc., written communication, 2002) was used as a basis for the MVB model (Figure 1). Model boundaries, hydraulic properties, and recharge and discharge datasets were defined for the MVB model using the UGTA model. Aquifer storage and time parameters were added to produce a transient model. Transient

model simulations were used to optimize hypothetical placement of a new pumping well or wells and pumping rates while staying within the drawdown limits. 


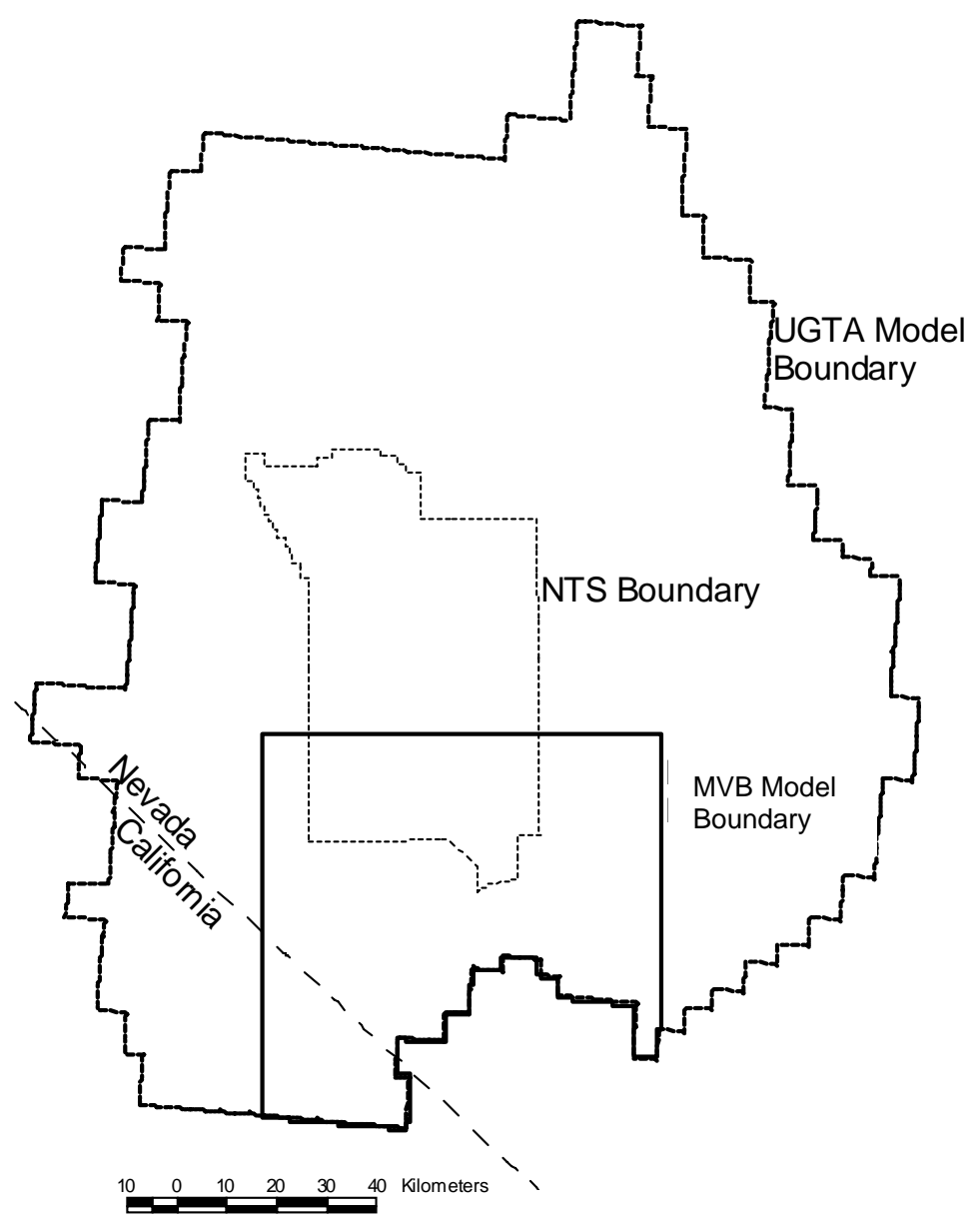

Figure 1. Map showing the MVB and UGTA model domains.

\section{METHODOLOGY}

\section{Code Selection}

This study was based on previous models created using the MODFLOW modeling package, so MODFLOW was chosen to be the code for the current study as well. Since MODFLOW is a finite-difference model, cells are defined in straight rows and columns throughout the domain and cannot follow undulating boundaries. The fine spacing of MVB model cells allowed relatively accurate placement of model boundaries and faults, so this was not a source of appreciable inaccuracy (Anderson and Woessner, 1992).

\section{Groundwater Flow Equation}

The flow equation used in MODFLOW combines Darcy's Law with the law of conservation of mass of fluid. The Darcy equation states that flow rate is dependent on the hydraulic conductivity of a medium and the three-dimensional gradient in hydraulic head

$$
q_{i}=-K_{i j} \frac{\partial h}{\partial x_{j}}
$$


where $i$ and $j$ are the Cartesian coordinate indices [L], $q$ is the flow rate [L/T], $K$ is the hydraulic conductivity $[\mathrm{L} / \mathrm{T}]$, and $h$ is the hydraulic head [L]. By stating that the mass of fluid in the system is conserved, water is allowed to change density, and therefore volume, because of compressibility, but the mass of fluid can only change as a result of unequal flow rates into and out of the system boundary. The combination of Darcy's Law and the law of conservation of mass results in the transient, three-dimensional, governing flow equation in MODFLOW

$$
\frac{\partial}{\partial x_{i}}\left(K_{i j} \frac{\partial h}{\partial x_{j}}\right)-q_{s}=S_{s} \frac{\partial h}{\partial t}
$$

where $i$ and $j$ are the Cartesian coordinate indices [L], $K_{i j}$ are the components of the hydraulic conductivity tensor and repeated indices imply summation [L/T], $h$ is the hydraulic head [L], $q_{s}$ is the volumetric flux of groundwater sources and sinks per unit volume [1/T], $S_{s}$ is specific storage [1/L], and $t[\mathrm{~T}]$ is time (Harbough et al., 2000; McDonald and Harbaugh, 1988).

Prior to creating the transient model, a steady-state model was created for comparison with the regional steady-state model. For a steady-state groundwater flow simulation, hydraulic heads are constant with respect to time, so the equation can be expressed as

$$
\frac{\partial}{\partial x_{i}}\left(K_{i i} \frac{\partial h}{\partial x_{i}}\right)-q_{s}=0
$$

The numerical implementation of groundwater pumping in MODFLOW does not account for changing transmissivity in single cells. Therefore, as the water level in a cell declines, the discharge remains the same. In reality, the discharge in a cell with a declining water level should decrease, and the remaining discharge, over the entire well screen, should be reallocated to other cells where the water levels have changed little. For transient modeling of the NTS groundwater flow system, no modification was made directly to the model code. Rather, when cells went dry during a simulation, discharge was redistributed to other cells manually based on effective transmissivity. If all cells associated with a well went dry, pumping rates were reduced.

\section{Steady-state Model}

The purpose of the steady-state model is twofold. First, simulated heads in the MVB model are compared against the UGTA regional model to ensure the two models are in general agreement. Second, the steady-state distribution of hydraulic heads are saved as starting heads for use in the transient model.

\section{MVB Model Domain}

Heads on the MVB boundary were not known exactly, therefore the model boundary was moved far from the area within the MVB. This boundary expansion allowed for inclusion of pumping wells located north of the MVB boundary in Jackass Flats and Frenchman Flat on the NTS. Inclusion of these pumping wells would be useful during transient model calibration since they are also far from the model boundary (Figure 2). The expansion also allowed analysis of the effect groundwater pumping had on the springs to the south of the MVB in the Ash Meadows area. 


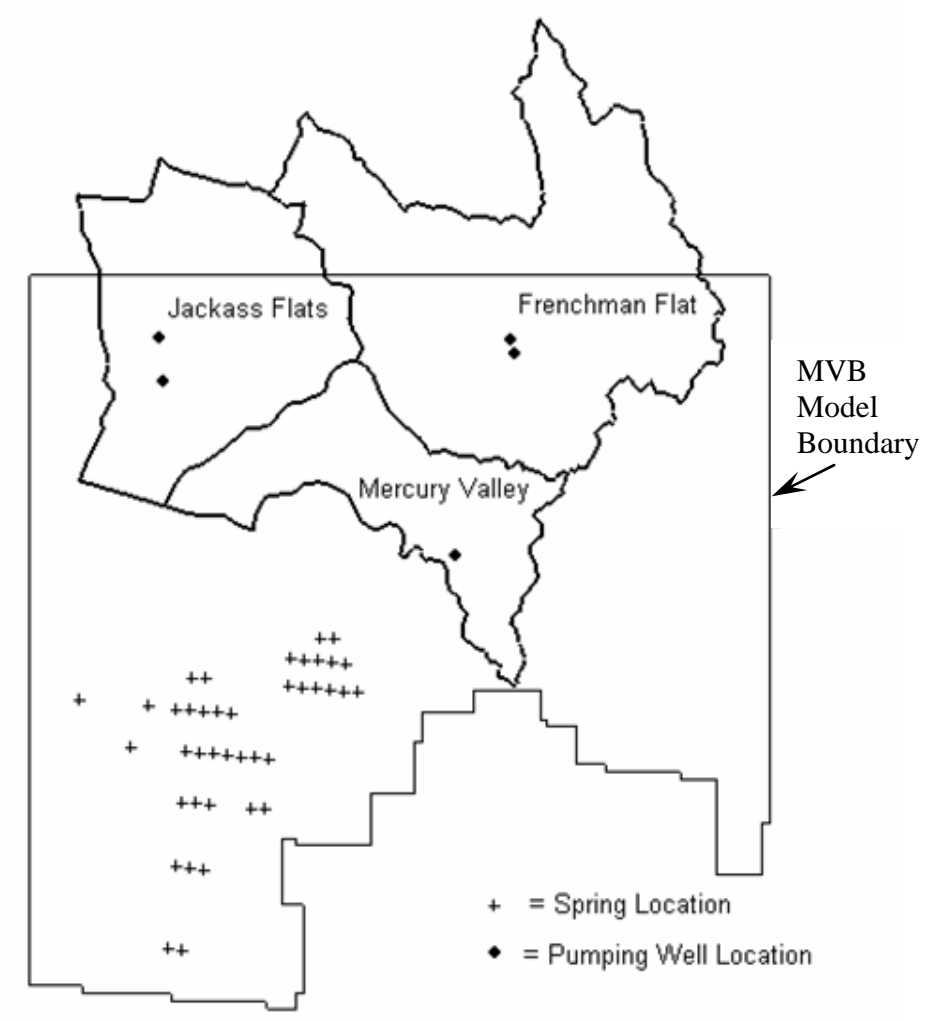

Figure 2. Map showing expanded MVB model boundary encompassing five water-supply wells and springs in the Ash Meadows area.

\section{Model Assumptions}

During construction of the steady-state MVB model, the following assumptions were made: 1) the pre-existing datasets created as inputs to and as outputs of the UGTA model (DOE, 1997) are the best available datasets for the scope of this study, 2) the model represents steady-state conditions representative of natural stresses to the system prior to groundwater development and underground nuclear testing, 3) recharge estimates based on the Maxey-Eakin methodology are representative of historical recharge rates, 4) the system is laterally anisotropic and vertically anisotropic, 5) each hydrostratigraphic unit (HSU) is homogeneous or can be divided into homogeneous zones, 6) the hydraulic conductivity is assumed to decrease in an exponential manner with increasing depth, and 7) flow within the model area can be described by the continuum, or representative elementary volume, approach.

Assumption 1 allows use of the UGTA model boundaries, layer elevations, and model assumptions as input into the MVB model. The UGTA model attributes have been quality checked by DOE and its contractors prior to use in the UGTA model as well as calibrated and verified against field-measured values (DOE, 1997). It is felt that the UGTA model inputs are more reliable than if they had been independently obtained and extrapolated in the course of the current study. 
Since the MVB inputs were based so closely on the UGTA regional model, and it assumed to be an accurate data source, the UGTA model should be discussed. In the following sections, MVB model construction is compared to a discussion of UGTA model construction. All information about the UGTA model was obtained from a recent DOE report on the construction of the UGTA flow model (DOE, 1997).

\section{Hydrostratigraphic Units and Layer Classification}

From the geologic model, stratigraphic units were identified and grouped into 20 HSUs underlying the UGTA model domain. Each layer of each HSU was assigned a representative horizontal hydraulic conductivity value, anisotropy ratio (defined as vertical hydraulic conductivity divided by horizontal hydraulic conductivity), and depth-decay coefficient. Within the MVB domain, eight of the 20 HSUs are not present. This allowed for elimination of some layers while still enhancing vertical accuracy of the MVB model, since several thin hydrologically important layers in the UGTA model did not need to be simulated in the MVB model.

Table 1 shows a comparison of MVB and UGTA model layers, top elevations, and thicknesses. Since HSU properties are depth-averaged in the UGTA model, the new HSUs defined for the MVB model were also depth-averaged. The top of the MVB model was defined at 1,500 $\mathrm{m}$ above sea level because the maximum elevation of the potentiometric surface within the MVB model domain is 1,420 m above sea level. Each layer thickness was uniformly defined as $100 \mathrm{~m}$.

Table 1. Comparison of UGTA and MVB model layer elevations and thicknesses.

\begin{tabular}{|c|c|c|c|c|c|}
\hline \multicolumn{3}{|c|}{ UGTA } & \multicolumn{3}{|c|}{ MVB } \\
\hline Model & Тор & Layer & Model & Тор & Layer \\
\hline Layer & Elevation (m) & Thickness (m) & Layer & Elevation (m) & Thickness (m) \\
\hline 1 & 2,000 & 250 & 1 & 1,500 & 100 \\
\hline 2 & 1,750 & 250 & 2 & 1,400 & 100 \\
\hline 3 & 1,500 & 150 & 3 & 1,300 & 100 \\
\hline 4 & 1,350 & 150 & 4 & 1,200 & 100 \\
\hline 5 & 1,200 & 150 & 5 & 1,100 & 100 \\
\hline 6 & 1,050 & 150 & 6 & 1,000 & 100 \\
\hline 7 & 900 & 200 & 7 & 900 & 100 \\
\hline 8 & 700 & 100 & 8 & 800 & 100 \\
\hline 9 & 600 & 125 & 9 & 700 & 100 \\
\hline 10 & 475 & 125 & 10 & 600 & 100 \\
\hline 11 & 350 & 125 & 11 & 500 & 100 \\
\hline 12 & 225 & 125 & 12 & 400 & 100 \\
\hline 13 & 100 & 150 & 13 & 300 & 100 \\
\hline 14 & -50 & 200 & 14 & 200 & 100 \\
\hline 15 & -250 & 250 & 15 & 100 & 100 \\
\hline 16 & -500 & 500 & 16 & 0 & 1,000 \\
\hline 17 & $-1,000$ & 500 & 17 & $-1,000$ & 1,000 \\
\hline 18 & $-1,500$ & 500 & 18 & $-2,000$ & 1,000 \\
\hline 19 & $-2,000$ & 1,000 & 19 & $-3,000$ & 1,000 \\
\hline 20 & $-3,000$ & 1,000 & & & \\
\hline
\end{tabular}


Conventionally, aquitards are represented as distinct model layers or with vertical conductance terms. This was not done in the UGTA model for two reasons. Many aquitards in the model domain are present only in isolated areas, and model layers must be continuous in MODFLOW. Also, faults in the Belted Range Thrust have vertical displacement greater than some model layer thicknesses. These layers separated by faults would have been computed as if they were still hydrologically connected, leading to inaccuracy. Therefore, every model layer was created with a constant top elevation and a constant thickness and contained one or more HSUs. The hydraulic properties of each cell within a layer were calculated as the weighted average of each HSU present. This resulted in many thin layers being necessary to preserve geologic complexity in areas such as Pahute Mesa and Yucca Flat. The UGTA model with 20 layers was found to adequately represent the complexity, while more layers did not significantly increase accuracy.

The lower seven layers of the UGTA model were classified as confined. This classification is based on the height of the potentiometric surface and indicates that the potentiometric surface will always be above the top elevation of the layer or the change in hydraulic head in the layer is less than 10 percent during model simulation. This classification is useful because it takes less computation time. The upper 13 layers of the model are classified as convertible (i.e., unconfined). This classification indicates that a layer can be either confined or unconfined depending on the location of the potentiometric surface during model simulation. Within the UGTA model domain, potentiometric surface varies from 1,600 m above mean sea level in the north to below sea level in Death Valley.

In the MVB model, the lower four layers were classified as confined, corresponding to depths between $4,000 \mathrm{~m}$ and $0 \mathrm{~m}$ below sea level. The upper 15 layers were classified as convertible, corresponding to depths between $0 \mathrm{~m}$ and 1,500 $\mathrm{m}$ above mean sea level.

\section{Grid Definition}

The UGTA model was created to quantify the risk of radioactively contaminated groundwater traveling outside the NTS boundary. Therefore, the model is most detailed around Pahute Mesa and Yucca Flat, where nuclear tests were conducted. Model cells measure $1.5 \mathrm{~km}$ by $1.5 \mathrm{~km}$ near testing areas where most geological and groundwater studies have been conducted. Cell size coarsens to $10 \mathrm{~km}$ by $10 \mathrm{~km}$ near the model boundaries, where less data exist and model accuracy is less important. The northwest corner of the model is in UTM Zone 11 located at 517,182 Easting, 4,230,435 Northing and covers an area of approximately $28,000 \mathrm{~km}^{2}$. The entire model grid is rotated five degrees clockwise to align model boundaries with average fracture direction in the nuclear testing areas. No-flow boundaries define most model boundaries because the boundaries coincide with flow barriers such as the tops of mountain ranges. At locations such as Eagle Mountain and Pahrump Valley, the boundary was modeled with a general head boundary because these mountain ranges do not impose flow barriers and underflow occurs in these areas. No significant surface water is transported into or out of the model boundary. A small creek transporting less than 1 cubic foot per second (cfs) was ignored during model construction because this outflow was insignificant compared to other flux sources.

The MVB model, on the other hand, was created to evaluate the volume of groundwater that could be extracted from the MVB for industrial use without creating a large amount of lateral or vertical drawdown. This model was centered on the MVB boundaries 
and extended to the north to include existing water-supply wells. These wells served as data points useful for checking accuracy of model-output values with respect to field-measured values. The MVB grid was aligned with north-south and east-west directions for ease of calculation. This was possible because no dominant fracture orientations are present in this area.

The MVB model grid covers an area of 4,997 $\mathrm{km}^{2}$ and is subdivided into 7,808 grid cells per layer. The northwest corner of the model is in UTM NAD 27, Zone 11 located at 540,000 Easting, 4,000,000 Northing. The maximum lateral extent of the model is $100 \times 100$ cells, but because of its irregular southern boundary many of these cells were inactivated. The horizontal cell size is constant at $800 \mathrm{~m}$ x $800 \mathrm{~m}$, and vertical spacing is $100 \mathrm{~m}$ per layer for the upper 15 layers and 1,000 m per layer for the four deepest layers. Because hydraulic conductivity in the area decreases with depth (DOE, 1997), the four deepest layers do not contribute significantly to the overall flow budget, and as such, did not require fine vertical grid spacing.

\section{Hydraulic Conductivity}

Since insufficient aquifer-test data existed from which to extrapolate hydraulic conductivity values to the entire UGTA model domain, it was assumed that all rocks of similar class had similar hydraulic properties and were assigned related hydraulic conductivity values. Data were used to estimate the hydraulic conductivity of three classes of HSUs within the flow system beneath the NTS (alluvial, carbonate, and volcanic). These datasets represent the best quality hydraulic conductivity and transmissivity data gained from regional-scale pumping and recovery test data that have little associated uncertainty (IT Corporation, 1996). Figure 3 shows the relationship of hydraulic conductivity to depth for each of these HSU classes. A semi-log relationship based on these datasets was used to populate the UGTA model cells with hydraulic conductivity values. The following equation describes this relationship:

$$
K_{\text {depth }}=K_{h}\left(10^{-\lambda d}\right)
$$

where $K_{\text {depth }}$ is the horizontal hydraulic conductivity at the specified depth [L/T], $K_{h}$ is the horizontal hydraulic conductivity at land surface $[\mathrm{L} / \mathrm{T}], \lambda$ is the depth-decay coefficient calculated from semi-log regression $[1 / \mathrm{L}]$, and $d$ is the depth as measured from land surface [L] (DOE, 1997). The derived depth-decay coefficient for the alluvial aquifer $\left(\lambda_{\mathrm{AA}}\right)$, volcanic aquifers $\left(\lambda_{\mathrm{VA}}\right)$, and the lower carbonate aquifer $\left(\lambda_{\mathrm{LCA}}\right)$, are $0.00563,0.00256$, and 0.00102 , respectively. The resulting hydraulic conductivity values were refined during calibration of the UGTA model to achieve best fit between model-generated and observed head values.

The lower boundary of both the UGTA and the MVB model was placed at 4,000 m below mean sea level. This is the maximum depth at which the lower carbonate aquifer is believed to be present. Below this depth exists low-permeability intrusives and the lower clastic confining unit. Data support 3,000 m below mean sea level as the maximum depth that significant flow occurs, so the lower boundary of the model is a conservative estimate that should take into account all flow. 


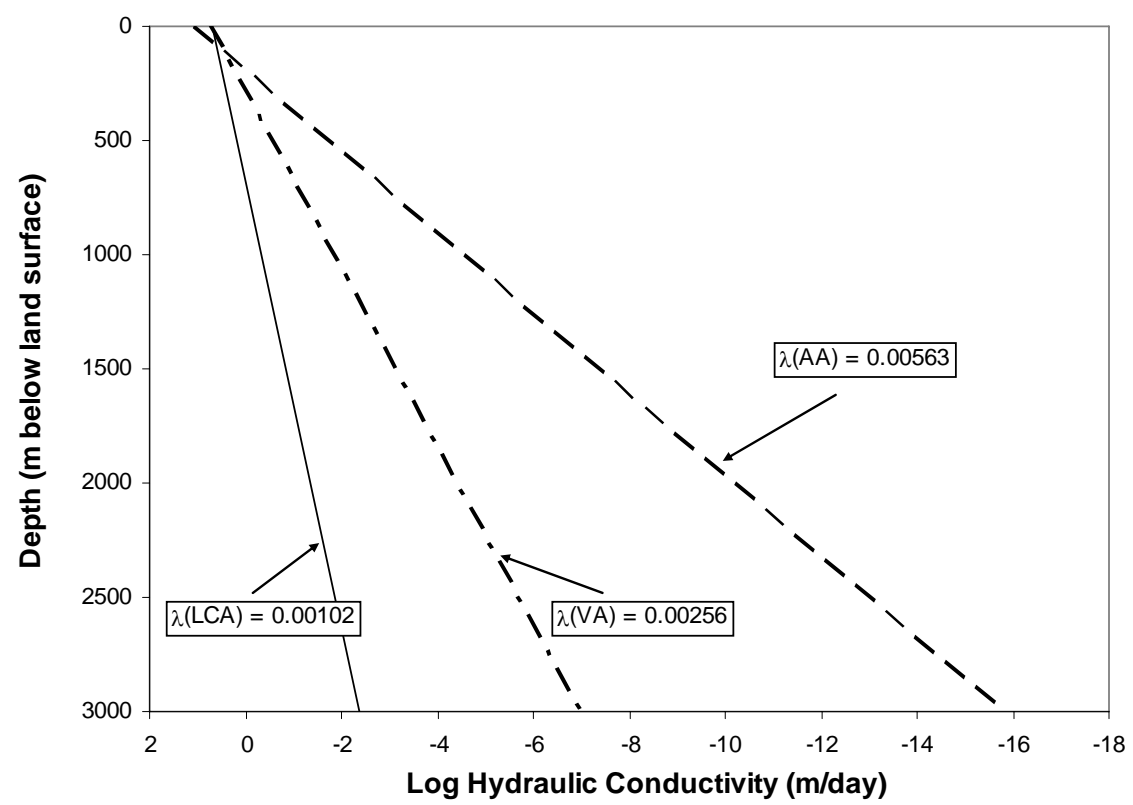

Figure 3. Graph comparing hydraulic conductivity of three classes of HSUs to depth below land surface.

An updated hydraulic conductivity dataset was obtained from the current UGTA database (Ken Rehfeldt, Shaw Environmental, personal communication, 2004). This is a database maintained by DOE that stores geologic and hydrologic data from the NTS from ongoing modeling versions and aquifer tests. The hydraulic conductivity dataset contained an estimated value for each cell in the UGTA model. Ordinary kriging, an advanced interpolation technique that takes into account the hydraulic conductivity value of every cell in the three-dimensional grid, was used to interpolate hydraulic conductivity values from the larger spacings of the UGTA model into the more finely spaced MVB grid.

\section{Vertical Conductance}

Vertical conductance is a parameter used in the UGTA model to quantify vertical flow between model layers. Since vertical hydraulic conductivity is almost always much less than horizontal hydraulic conductivity, this parameter is commonly referred to as leakance and indicates the flow rate between model layers. Vertical conductance values also depend on the HSU class and are calculated using a weighted average method as

$$
\text { Vcont }_{i, j, k+\frac{1}{2}}=\frac{1}{\sum_{g=1}^{n} \frac{\Delta z_{g}}{K_{v g}}}
$$

where $g$ designates a particular HSU, $K_{v g}$ is the vertical hydraulic conductivity of the HSU layer $g$ [L/T], $i, j, k+1 / 2$ is the vertical interval between node $\mathrm{i}, \mathrm{j}, \mathrm{k}$ and node $\mathrm{i}, \mathrm{j}, \mathrm{k}+1$ [L], and $\Delta z_{g}$ is the thickness of layer $g[\mathrm{~L}]$. 
Vertical hydraulic conductivity is the product of horizontal hydraulic conductivity and the weighted average of the anisotropy ratios of the HSUs present in the model cell. In the MVB model, vertical hydraulic conductivity and horizontal anisotropy ratio were used as inputs rather than the vertical conductance parameter. MODFLOW-2000, the newer version of MODFLOW, allowed for these inputs, which results in less round-off error than conducting the calculation outside the modeling software. Anisotropy was also used to indicate the presence of a fault or other area of uncommonly high hydraulic conductivity between cells. This method of including effects from faults enabled the use of standard MODFLOW software rather than the proprietary software MODFLOWP used in the study by Carroll et al. (2003). Vertical hydraulic conductivity and horizontal anisotropy datasets were obtained from the DOE database.

\section{Boundary Conditions}

Boundary conditions must be defined at each cell on the model's lateral and vertical edges to solve the groundwater flow equation. Head-dependent flux boundaries were included in the MVB model at three locations on the southern boundary. These locations are identical to the head-dependent boundaries as specified in the DOE regional model. The head-dependent boundaries are implemented in MODFLOW by using the General Head Boundary package. Head-dependent flux boundaries are defined by an adjacent hydraulic head, and a conductance term, which represents the hydraulic conductivity and the length to the specified head. MODFLOW then calculates the flux at the boundary based on the difference between the specified head adjacent to the boundary and the head as calculated within the model. The three locations where head-dependent boundaries were specified represent underflow through Eagle Mountain and Pahrump Valley as shown in Figure 4. Less than $2,000 \mathrm{~m}^{3}$ /day net discharge exited through these head-dependent boundaries during steady-state flow simulations. The target flux range for the Eagle Mountain discharge area is between 850 and $3,400 \mathrm{~m}^{3} /$ day outflow (IT Corporation, 1996). The target flux range for the Pahrump Valley area is between 5,000 and 7,600 $\mathrm{m}^{3} /$ day inflow (IT Corporation, 1996). Therefore, the target flux range for the head-dependent boundary cells is between 1,600 and $6,750 \mathrm{~m}^{3} /$ day.

A constant- or specified-head boundary was applied everywhere else along the north, south, east, and west sides of the model. Hydraulic-head values from the most recent revision of the DOE database defined the constant-head elevation at each boundary cell. Choosing a specified-head condition for the majority of the model boundary is a valid modeling strategy since the boundary is far from the area of interest. During flow simulations, however, water is drawn across specified-head boundaries into the model with no decrease in water supply or water-table elevation at the boundary. This may not accurately model the system when extracting water at a fast rate or high volume. Water supply to springs south of the MVB may be decreased because of a decrease of available water that naturally replenishes them from the north through the MVB if high pumping rates occurred in the area. A no flow boundary was placed along the entire lower boundary of the model because no flow is assumed to occur below this depth. 


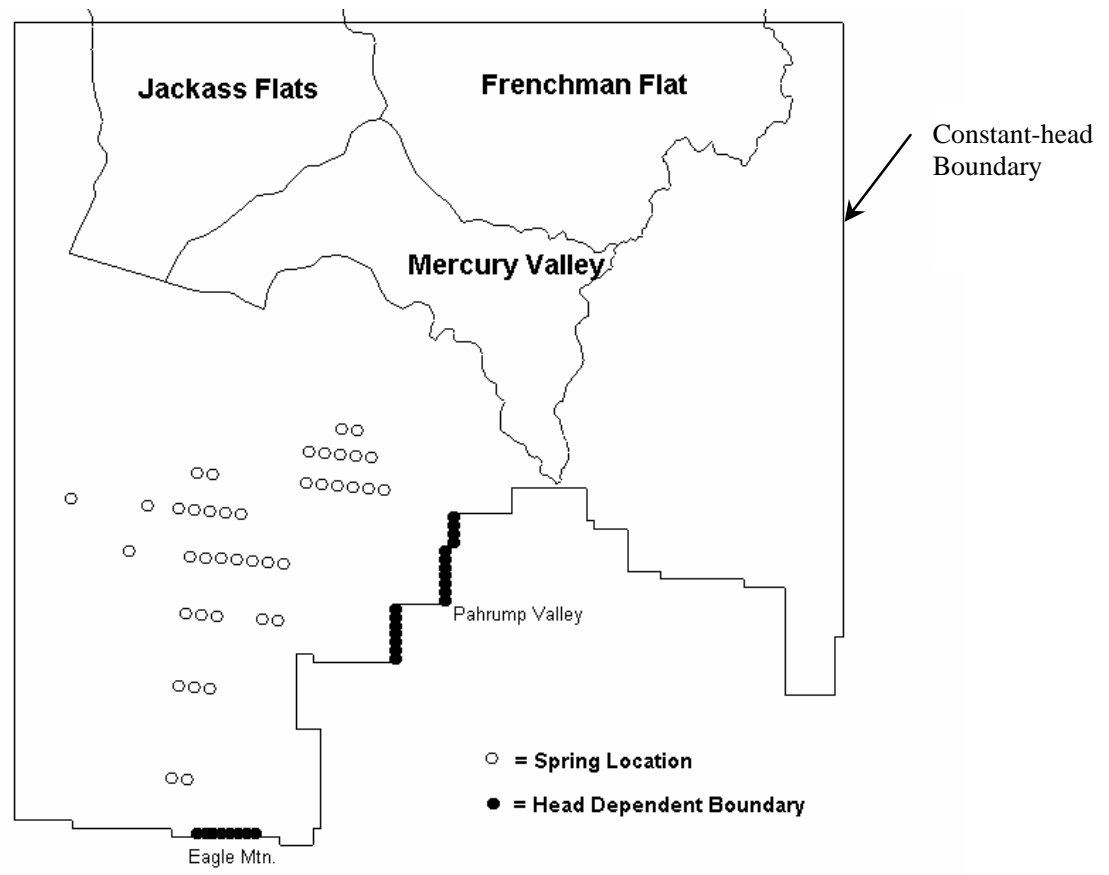

Figure 4. Map of the MVB model domain showing spring locations and head-dependent flux boundary locations. Constant-head boundaries are located along thin black lines defining the model domain.

Model Fluxes

Influxes of water to the MVB model resulted from recharge from precipitation and underflow from outside the model boundary. Discharges of water from the MVB model resulted from losses from evapotranspiration, spring flow, and underflow across model boundaries. Since the MVB model was based upon the steady-state UGTA model, discharges from groundwater pumping were initially not considered.

To simulate recharge from the infiltration of precipitation to the water table, a value for recharge rate (m/day) was specified for the highest active cell on the model's upper boundary in both the UGTA and MVB models. The recharge package in MODFLOW was used to apply these rates to the top layer of the model. The dataset used for the UGTA model was generated using precipitation and elevation data, a modified Maxey-Eakin method (Maxey and Eakin, 1949; IT Corporation, 1996) and the Hardman precipitation map of Nevada (Hardman, 1936). The modified Maxey-Eakin method estimates recharge to the water table as a function of the amount of precipitation, distance from land surface to the water table, rock or soil type at the surface, and presence or absence of surface water (IT Corporation, 1996). Recharge for the MVB model domain was calculated during the study by interpolating the most recent two-dimensional recharge dataset from the DOE database to the MVB model domain. The recharge rates varied from 0 to $2 \times 10^{-4} \mathrm{~m} / \mathrm{day}$, with an average recharge rate of $3 \times 10^{-6} \mathrm{~m} /$ day. This dataset was obtained from the DOE database (Ken Rehfeldt, Shaw Environmental, personal communication, 2004). The modified Maxey-Eakin method resulted in a total recharge of about 14,000 $\mathrm{m}^{3} /$ day for the entire MVB model domain. This simulated rate is less than the recharge rate of about $23,000 \mathrm{~m}^{3} /$ day determined by NDWR using the strict Maxey-Eakin method for the MVB. If the rate of 23,000 $\mathrm{m}^{3} / \mathrm{day}$ had been used, higher pumping rates may have been achieved. 
The Drain Package was used to simulate water leaving the model as spring discharge and evapotranspiration. Areas that contain vegetation or spring locations were identified as surface discharge areas in the models. Within the model domain, water that is discharged by springs quickly reinfiltrates the groundwater system or is lost to the atmosphere through evapotranspiration. The Evapotranspiration (ET) Package in MODFLOW could have been used to simulate evapotranspiration losses, however, the ET package uses a discontinuous mathematical function that has proven unstable in past modeling efforts and cannot simulate increased discharge from rising head levels. For these reasons, the more flexible Drain Package was chosen to simulate spring and evapotranspiration losses in both the UGTA and MVB models.

Drain elevation and conductance are the required inputs for the Drain Package. Drain elevation was set at the maximum depth that groundwater can be evapotranspired. This depth is referred to as the extinction depth and was set to $3.05 \mathrm{~m}$ below land surface elevation. Conductance is a measure of all head losses from all springs in a discharge area. It was estimated with the following formula:

$$
\text { Cond }_{i, j, k}=\frac{A_{i, j, k}}{A_{D . A .}} \times \frac{\text { Flux }_{D . A .}}{\left(h_{i, j, k}-d_{i, j, k}\right)}
$$

where Cond $_{i, j, k}$ is the conductance of drain cell $i, j, k\left[\mathrm{~L}^{2} / \mathrm{T}\right], A_{i, j, k}$ is the area of drain cell $i, j, k$ $\left[\mathrm{L}^{2}\right], A_{D . A}$. is the total area of the specified discharge area $\left[\mathrm{L}^{2}\right]$, Flux $_{D . A}$. is the total estimated discharge flux from the specified discharge area $\left[\mathrm{L}^{2}\right], h_{i, j, k}$ is the head in drain cell $i, j, k[\mathrm{~L}]$, and $d_{i, j, k}$ is the drain elevation in cell $i, j, k[\mathrm{~L}]$.

Springs included within the MVB model domain are all part of the Ash Meadows wetland area and are environmentally sensitive. The reaction of these springs was closely monitored during flow modeling. See Figure 4 for head-dependent flux boundary locations. A total of 112,560 $\mathrm{m}^{3}$ /day was discharged through springs in the MVB model.

\section{Transient Model Development}

To create the transient model, pumping well data, time step information, and storage parameters were added to the steady-state model. The derivation and implementation of the transient model components are described below.

\section{$\underline{\text { Storage Parameters }}$}

In 2001, Belcher et al. published a paper summarizing hydraulic parameter estimates developed from aquifer tests performed in the Death Valley regional flow system. The dataset available for this study gives estimates for specific yield and storativity of each HSU in the flow system; these estimates were developed for both the USGS and UGTA flow models (Belcher et al., 2001). Specific-yield values from the Belcher et al. (2001) dataset were kriged to fit into MVB cells and added to the model. Specific storage is equal to storativity divided by thickness. Storativity values in the database were divided by the thickness of the corresponding HSU to obtain specific-storage values. Similar to specific yield, storativity was kriged and added to the model. 


\section{Pumping Well Data}

Data from the five existing pumping wells located within the MVB model domain were used to define water-level response to pumping stresses. The approximate location of these wells within the model domain is shown in Figure 5. Well locations in UTM coordinates and well construction details are given in Table 2. A complete monthly dataset of pumping rates for the five wells exists for the time period between January 1, 1983, and July 1, 2004. A consistent dataset of water-level measurements also exists for four of these five wells over the same time period. All pumping well data were obtained from the USGS/USDOE Cooperative Studies in Nevada website (http://nevada.usgs.gov/doe_nv/, August 2004). Pumping wells used for model verification include:

- Army \#1 Water Well - Mercury Valley

- J-12 and J-13 Water Wells - Jackass Flats

- Water Wells 5B and 5C - Frenchman Flat

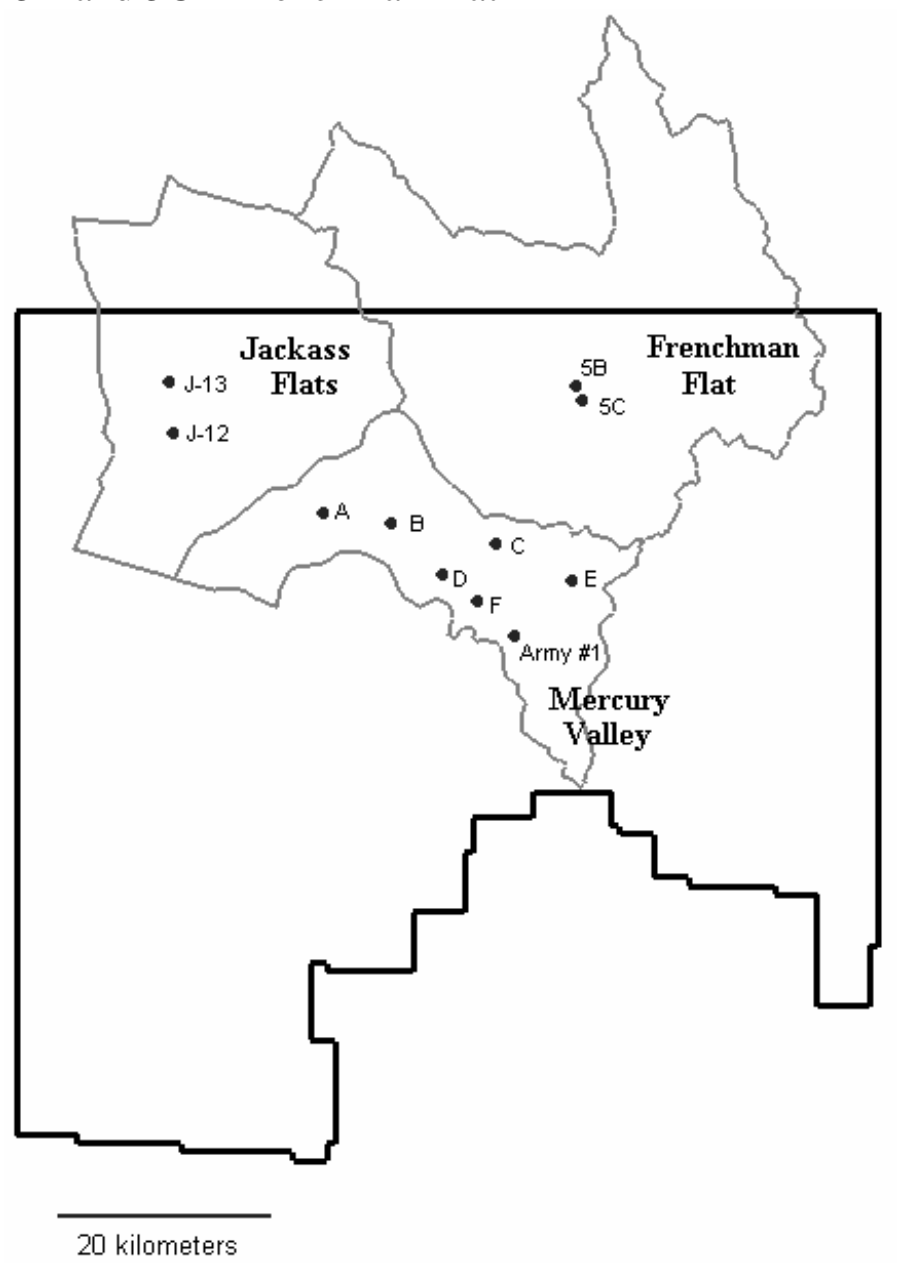

Figure 5. Location of existing water-supply wells: Army \#1 Water Well, Water Well 5B, Water Well 5C, J-12 Water Well, and J-13 Water Well. The three Nevada administrative groundwater basins in the MVB model domain are also shown as are hypothetical water-supply wells A through F. 
Table 2. Summary of location, slotted/open interval elevation, static water-level elevation, baseline pumping rate, and horizontal hydraulic conductivity for existing water-supply wells in the MVB flow model. Horizontal hydraulic conductivity is reported at $650 \mathrm{~m}$ above mean sea level (model layer 8).

\begin{tabular}{|c|c|c|c|c|c|c|c|}
\hline Well ID & Basin & $\begin{array}{l}\text { UTM East } \\
(\mathrm{m})\end{array}$ & $\begin{array}{l}\text { UTM North } \\
(\mathrm{m})\end{array}$ & $\begin{array}{l}\text { Open Interval } \\
\text { (m MSL) }\end{array}$ & $\begin{array}{l}\text { Static WL } \\
\text { (m MSL) }\end{array}$ & $\begin{array}{l}\text { Baseline } \\
\left(\mathrm{m}^{3} / \text { day }\right)\end{array}$ & $\begin{array}{l}\text { Horiz. K } \\
\text { (m/day) }\end{array}$ \\
\hline Army \#1 WW & Mercury & 586119.8 & 4049799.7 & $\begin{array}{l}641.3 \text { to } 687.3 \\
366.0 \text { to } 546.8\end{array}$ & 721.31 & $\begin{array}{l}161.89 \\
484.11\end{array}$ & 43.25 \\
\hline WW 5B & Frenchman & 591978.2 & 4073118.7 & 668.1 to 729.0 & 732.98 & 225.17 & 0.001 \\
\hline WW 5C & Frenchman & 592478.2 & 4071749.4 & 577.3 to 668.7 & 720.11 & 190.39 & 0.01 \\
\hline J-12 WW & Jackass & 554435.8 & 4068767.1 & $\begin{array}{l}689.4 \text { to } 712.3 \\
606.8 \text { to } 683.6\end{array}$ & 727.98 & 168.57 & 0.68 \\
\hline$J-13$ WW & Jackass & 554020.6 & 4073516.0 & $\begin{array}{r}527.3 \text { to } 647.4 \\
(-58.2) \text { to } 131.4\end{array}$ & 728.66 & 0.95 & 0.33 \\
\hline
\end{tabular}

Only water-level measurements representing static water-level conditions were included in the dataset for pumping wells $\mathrm{J}-12, \mathrm{~J}-13,5 \mathrm{~B}$, and $5 \mathrm{C}$

(http://nevada.usgs.gov/doe_nv/, August 2004). Water-level measurements taken when a well was pumping or after it was recently pumped were discarded.

As shown in Table 2, pumping wells Army \#1 Water Well, J-12 Water Well, and J-13 Water Well were constructed with two slotted intervals. J-12 Water Well has only a 5.8-m gap between the slotted intervals, both of which occur within model layer 8 . This well was treated as having a single continuous slotted interval. J-13 Water Well has a 120.1-m slotted interval in layers 9 and 10 and a 189.6-m slotted interval in layers 14 through 16. This well was modeled with only its upper slotted interval since the decrease in hydraulic conductivity with depth resulted in more than 95 percent of flow coming from the upper interval. Army \#1 Water Well has a 46-m slotted interval in layer 8 and a 180.8-m slotted interval in layers 10 through 12. This was simulated as two separate wells with slotted intervals in nonsequential layers of the model that occupy the same model column. The pumping rate in each affected cell was weighted based on each cell's transmissivity. The slotted interval in layer 8 contributed 25.06 percent of the flow, and the lower slotted interval contributed 74.94 percent of flow.

\section{Pumping Scenarios}

The MVB transient model was used to simulate three separate pumping scenarios. A total simulation time of 29,220 days (80 years) was utilized for each transient simulation.

a. Baseline Stress Scenario: The baseline scenario was conducted using the average pumping rate of the five existing pumping wells from July 2003 to July 2004; see Table 2 for these rates. This scenario provides very little stress to the flow system and was used as the baseline to which the drawdown effects of maximum stress scenarios at model boundaries and springs would be compared.

Background pumping was included in the baseline stress scenario because pumping was occurring when head measurements were taken by the USGS, and this provided a means of model verification. For verification, head measurements taken during baseline pumping were compared to head level predictions output by the MVB flow model when actual pumping rates were used as inputs. 
b. Maximum Stress Scenario: The maximum stress scenario for the MVB model was conducted using the 2003-2004 average pumping rates for the four wells in Jackass Flats and Frenchman Flat (J-12, J-13, 5B, and 5C) and the maximum pumping rate that would satisfy the drawdown criteria stated previously for Army \#1 Water Well. These criteria were to create a maximum drawdown of $0.5 \mathrm{~m}$ at MVB boundaries relative to a steady-state, no-pumping scenario and to maintain water-table elevation at the wellbore within the screened portion of the well.

c. Optimization Simulations: Seven scenarios were run that tested six individual hypothetical well locations and one scenario that tested all six hypothetical well locations pumping simultaneously. Hypothetical pumping well locations and hydraulic conductivity values are listed in Table 3. All optimization simulations were run while pumping the five existing water-supply wells at baseline rates. The individual optimization scenarios tested the output capacity of different locations within the MVB while satisfying drawdown criteria. The seventh simulation combined pumping from all six hypothetical well locations so that drawdown within the basin could be minimized and groundwater withdrawal maximized. The locations of existing and hypothetical water-supply wells can be seen in Figure 5.

Table 3. Summary of location, slotted/open interval elevation, and horizontal hydraulic conductivity value for the six hypothetical water-supply wells in the MVB model. Horizontal hydraulic conductivity is reported at $650 \mathrm{~m}$ above mean sea level (model layer $8)$.

\begin{tabular}{cccccc}
\hline $\begin{array}{c}\text { Hypothetical } \\
\text { Well }\end{array}$ & Basin & $\begin{array}{c}\text { UTM East } \\
(\mathrm{m})\end{array}$ & $\begin{array}{c}\text { UTM North } \\
(\mathrm{m})\end{array}$ & $\begin{array}{c}\text { Open/Slotted Interval } \\
\text { (m MSL) }\end{array}$ & $\begin{array}{c}\text { Horizontal K } \\
\text { (m/day) }\end{array}$ \\
\hline A & Mercury & 568400.0 & 4061200.0 & 600 to 800 & 101.35 \\
B & Mercury & 574800.0 & 4060400.0 & 600 to 800 & 108.14 \\
C & Mercury & 584400.0 & 4058000.0 & 600 to 800 & 67.57 \\
D & Mercury & 579600.0 & 4055600.0 & 600 to 800 & 97.62 \\
E & Mercury & 591600.0 & 4054800.0 & 600 to 800 & 62.09 \\
F & Mercury & 582800.0 & 4053200.0 & 600 to 800 & 106.53 \\
\hline
\end{tabular}

The location of hypothetical wells was based on two criteria: proximity to the MVB boundary and the value of horizontal hydraulic conductivity of the corresponding model cell within model layer 8 . Since Mercury Valley is a very sparsely populated area and has great expanses of desert topography, risk of a manmade or natural structure interfering with well placement is low. However, if interference did occur, the model domain measures $80 \mathrm{~km}$ in the east-west direction and wells could easily be moved to a nearby location with similar water availability. Model layer 8 corresponds to the centroid elevation of $650 \mathrm{~m}$ above sea level and was chosen as the representative elevation for results reporting because it was the shallowest layer to be pumped at a sustainable rate in previous testing without going dry. This shallow layer would therefore minimize well construction costs and not be affected by small changes in water-table elevation.

The horizontal hydraulic conductivity field within the MVB domain has values ranging from 0 to $236.4 \mathrm{~m} /$ day. As seen in Figure 6, hypothetical wells were placed in zones 
of relatively high hydraulic conductivity (62.09 to $108.14 \mathrm{~m} /$ day) while maintaining distance between the well and the groundwater basin boundary. This high conductivity zone is based upon the high conductivity of the Lower Carbonate Aquifer, which is a common regional rock type in the Death Valley regional flow system (Fiero, 1986; Sweetkind et al., 2004). The Lower Carbonate Aquifer hydrostratigraphic unit is widespread in the UGTA flow model, as well. Each hypothetical well was simulated with a 200-m slotted interval from 600 to $800 \mathrm{~m}$ above mean sea level.

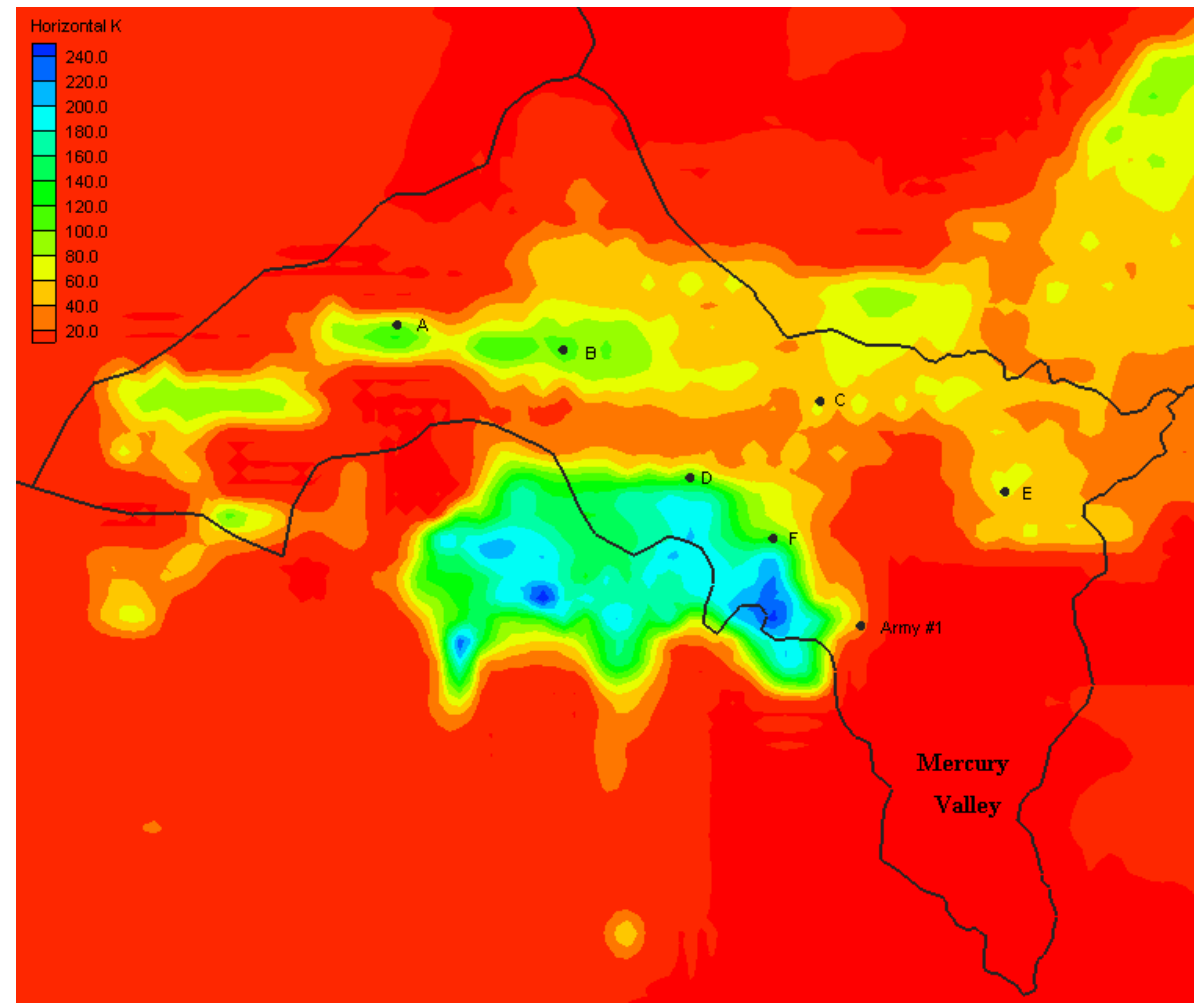

Figure 6. Horizontal hydraulic conductivity field for model layer 8. Contour interval is $20 \mathrm{~m}$.

During the baseline simulation, each of the five existing pumping wells were pumped at 2003-2004 average rates for the entire 80 -year period. The combined rate of $1,231 \mathrm{~m}^{3} /$ day is very low compared to the perennial yields of the three groundwater basins and was expected to induce little or no stress on the flow system. During the maximum stress scenario, the first 40-year period simulated baseline pumping rates at the four existing wells in Jackass Flats and Frenchman Flat. Simultaneously, Army \#1 Water Well was pumped at a rate such that additional withdrawals did not exceed the perennial yield $\left(27,036 \mathrm{~m}^{3} /\right.$ day $)$ nor compromise the drawdown criteria of a maximum of $0.5 \mathrm{~m}$ at the basin boundary while maintaining drawdown within the screened interval of the well. In the hypothetical maximum stress scenarios, one well, or a combination of wells, was pumped at the maximum percentage of Mercury Valley's perennial yield that could be sustained for the first 40-year period while honoring the drawdown criteria. The last 40 years simulated drawdown recovery after pumping above baseline rates had stopped. Each of the five existing wells also continued pumping at their 2003-2004 average rates through the entire simulation. 


\section{MVB MODEL RESULTS}

\section{Steady-state Model Results}

Modeled Heads

No additional calibration beyond what was accomplished implicitly by UGTA model development was performed on the MVB steady-state model. During a model run, the groundwater flow equation is iteratively solved for hydraulic-head elevation at each cell in the model. The model outputs a final solution when the difference in head values at each cell and the flux values at boundary cells between current and previous model iterations are less than a specified value, called the convergence criteria. For the MVB model convergence criteria, head change was set to $0.005 \mathrm{~m}$ and flux residual set to $0.25 \mathrm{~m}^{3} /$ day. These values resulted in a mass-balance error of less than 0.01 percent.

The model solution was converted to a contour map of hydraulic-head values and compared visually to the hydraulic-head solution output by the UGTA model. The two outputs exhibited similar head elevations and contours. Since the UGTA model was created using very similar or identical datasets and a thorough calibration of its solution was conducted previously, a steady-state calibration was not performed on the MVB model. Steady-state heads from the MVB model were subsequently used as initial heads for the transient model.

\section{Water-balance Analysis}

Water-budget analyses were conducted to quantify the difference between water influxes and outfluxes within the MVB model domain and the degree of agreement between the regional UGTA model and the detailed MVB model. The software program ZoneBudget creates a water budget for any specified area within a MODFLOW groundwater model (Harbaugh, 1990). This program was used to extract just the portion of the UGTA model that corresponds to the MVB model domain. See Table 4 for a comparison of water inputs and outputs of the MVB model and a corresponding area of the UGTA model. The percent difference was calculated as

$$
\frac{\text { Flux }_{U G T A}-\text { Flux }_{M V B}}{\text { Flux }_{U G T A}} \times 100 \%
$$

The large percent difference between some fluxes in the MVB and the UGTA models, especially in recharge fluxes, is caused by unequal areas being compared. The UGTA model domain area could not be exactly duplicated by the MVB model because of differing cell sizes and the five-degree rotation of the UGTA model. More of the Spring Mountains recharge is calculated in the UGTA model than in the MVB model. However, error was considered small enough to continue with the transient model. 
Table 4. Flux comparison of MVB model and a corresponding volume of the UGTA model domain.

\begin{tabular}{|c|c|c|c|c|}
\hline & Fluxes ( $\mathrm{m}^{3} /$ day) & Steady-state MVB & Steady-state UGTA & \% Difference \\
\hline \multirow[t]{4}{*}{ In } & Constant-head Boundaries & $1.6699 \mathrm{E}+05$ & $1.7932 \mathrm{E}+05$ & 6.9 \\
\hline & Head-dependent Boundaries & $3.2510 \mathrm{E}+03$ & $3.3016 \mathrm{E}+03$ & 1.5 \\
\hline & Recharge & $1.4649 \mathrm{E}+04$ & $1.9452 \mathrm{E}+04$ & 24.7 \\
\hline & Total In & $1.8489 \mathrm{E}+05$ & $2.0208 \mathrm{E}+05$ & 8.5 \\
\hline \multirow[t]{6}{*}{ Out } & Constant-head Boundaries & $6.8023 \mathrm{E}+04$ & $5.7359 \mathrm{E}+04$ & 18.6 \\
\hline & Head-dependent Boundaries & $4.2379 \mathrm{E}+03$ & $7.3639 E+03$ & 42.5 \\
\hline & Springs & $1.1256 \mathrm{E}+05$ & $1.3734 \mathrm{E}+05$ & 18.0 \\
\hline & Total Out & $1.8483 \mathrm{E}+05$ & $2.0206 \mathrm{E}+05$ & 8.5 \\
\hline & In - Out & 63.620 & 18.169 & \\
\hline & \% discrepancy & 0.03 & 0.01 & \\
\hline
\end{tabular}

\section{Transient Model Results}

Transient Model Calibration

Simulated results show that most of the water extracted from beneath Mercury Valley comes from storage, so specific yield is a very important input to the model. Calibration to best match simulated heads with observed values was accomplished by adjusting a multiplication factor to the DOE specific-yield dataset given the baseline scenario. Best agreement between target and simulated heads was accomplished using a multiplication factor of one. Specific-yield values used in the MVB flow model range from 0 to 0.01 , and the mean specific yield value was 0.0067 .

\section{Transient Model Verification}

The transient model was first used to simulate the time period between January 1 , 1983, and July 1, 2004. Twelve time steps per year were output to create a transient water-table elevation dataset that could be compared with actual water-table elevations over this time period. The USGS water-level measurements were used to verify the ability of the MVB model to simulate water-level trends as compared to observed water-level data measured in pumping wells with no additional calibration.

The transient model was able to predict general water-level trends induced by changes in pumping within the MVB (Figure 7). The average water-table elevation of the measured data distributions in Figure 7 was normalized to the simulated data distribution average. This was done because it was important to evaluate the similarity of increasing or decreasing trends rather than absolute values. Since transient responses such as changes in recharge were not accounted for, agreement between absolute values was not expected. Response simulation of Army \#1 Water Well was accurate to within $1 \mathrm{~m}$ throughout the entire 17-year simulation period, note that vertical change on the y-axis is $3 \mathrm{~m}$. Only one water-table elevation measurement exists for Water Well 5C over the period of interest, so no comparison could be analyzed. However, a consistent record of pumping rates does exist for Water Well 5C, which was an important factor in explaining the sharp drop in simulated piezometric surface elevation of nearby Water Well 5B. Response of Water Well 5B to actual pumping rates was 

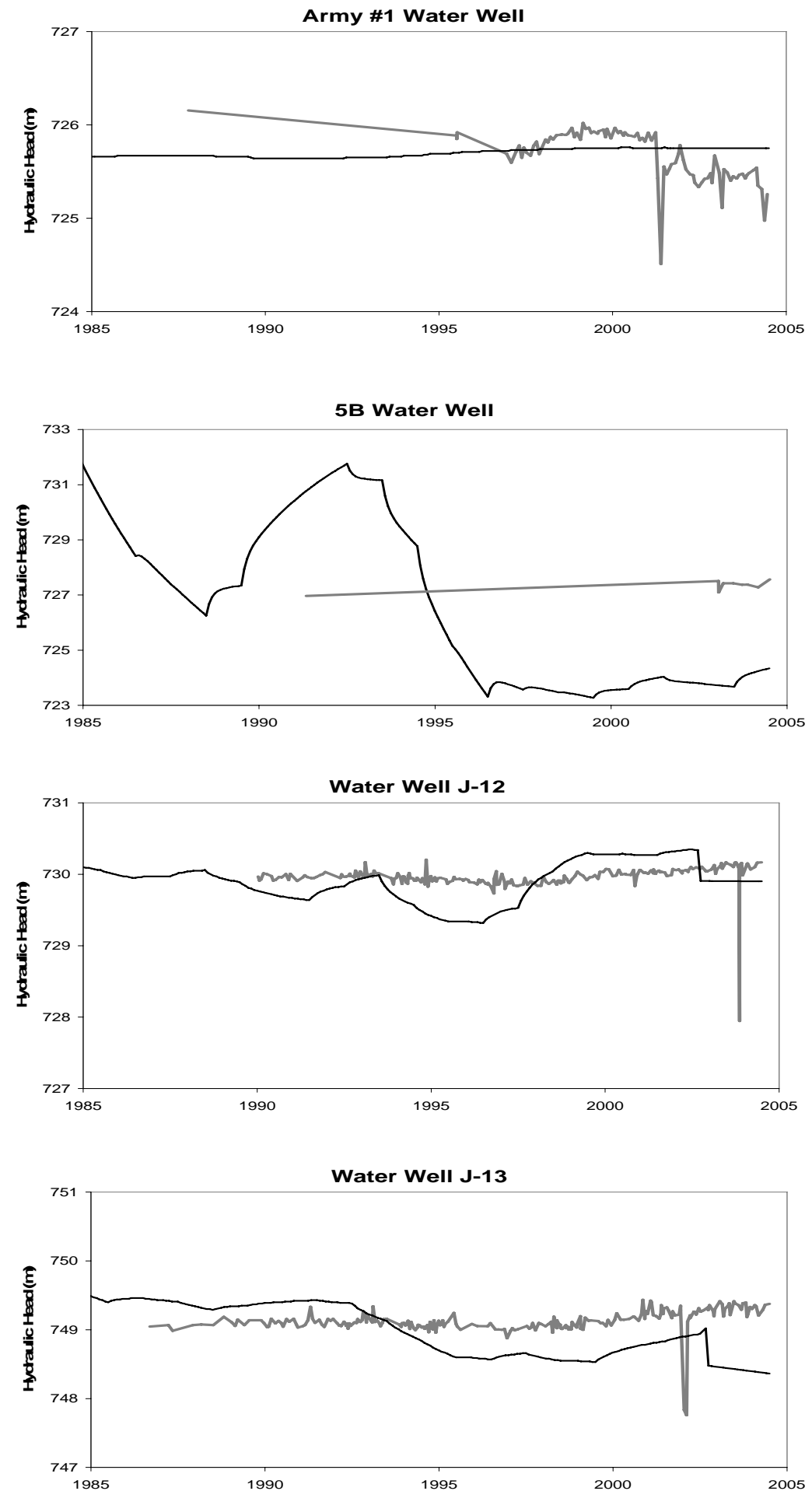

Figure 7. A graph for each existing water-supply well that had a USGS water-level dataset. Each graph shows the simulated hydraulic-head elevation in black and the measured head elevation in gray. 
predicted correctly within $5 \mathrm{~m}$ throughout the simulation. The response of J-12 Water Well was predicted to within less than $1 \mathrm{~m}$ during the 15-year simulation period except for one low spike in measured head. This spike may be because of the measurement being taken soon after pumping ceased. Simulation of J-13 Water Well was also accurate to less than $1 \mathrm{~m}$ except for a single low spike. This spike could also be because of taking the head measurement soon after pumping had ceased in the well.

The model was then programmed to simulate 80 years into the future, recording model outputs five times each year. The first 40 years in the simulation represented a series of different pumping stress scenarios and the second 40 years represented the water-level recovery period when pumping above baseline rates had ceased.

\section{Baseline Stress Scenario}

For the baseline stress scenario, 2003-2004 average pumping rates from the five existing water-supply wells were used. These rates, well locations, and screened intervals are listed in Table 2. Most of these wells receive water from multiple model layers since they have long open intervals and effects to model layer 8 are reported here for comparison with hypothetical well stress scenarios.

Head change in the baseline stress scenario varied significantly between wells. The greatest simulated drawdown in a well cell was $13.9 \mathrm{~m}$ in Water Well 5C in Frenchman Flat. Hydraulic conductivity in the cell containing Water Well 5C is 0.01 $\mathrm{m} /$ day, the cell is surrounded by a low conductivity area, and it is adjacent to the cell containing Water Well 5B, which is simultaneously drawing water. Drawdown in J-13 Water Well in Jackass Flats and Army \#1 Water Well in Mercury Valley was negligible. The lateral extent of drawdown of each well was well within groundwater basin boundaries at the $0.5-\mathrm{m}$ contour. The head change with respect to simulated time is illustrated in Figure 8 for all five wells.

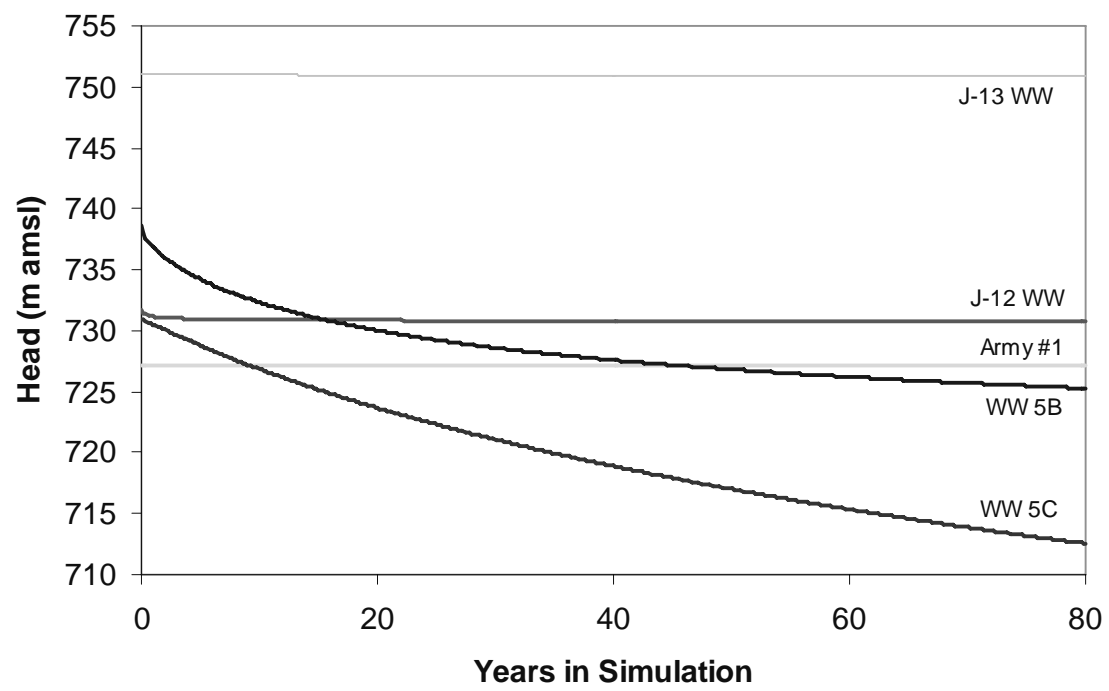

Figure 8. Water-level elevation during baseline stress scenario for the five model cells containing existing wells in the MVB model domain. 


\section{Mercury Valley Maximum Stress Scenario}

Water available for withdrawal is evaluated by examining withdrawal rates, areal extent of drawdown, and corresponding changes to the volumetric water budgets between the steady-state and the stressed simulations. Note the steady-state model was run with no pumping occurring in any well in the model domain. This is different from the discussion of baseline stress scenarios.

Existing pumping wells in Frenchman Flat and Jackass Flats were continually pumped at the 2003-2004 average rates. Pumping from Army \#1Water Well was first simulated at 100 percent perennial yield, but lateral drawdown extended west far beyond the groundwater basin boundary. Withdrawal could be simulated at a maximum pumping rate of $13,518 \mathrm{~m}^{3}$ /day while limiting drawdown at the basin boundary to $0.5 \mathrm{~m}$. This pumping rate corresponds to 50 percent of the perennial yield as defined by Scott et al. (1971). Figure 9 shows the $0.5 \mathrm{~m}$ lateral drawdown contour caused by the 50 -percent stress scenario. The $1.0 \mathrm{~m}$ drawdown contour is too small to be shown. Drawdown in the well cell and well cell recovery as functions of simulation time for the Army \#1 Water Well maximum stress scenario and the six hypothetical well maximum stress scenarios are shown in Figure 10. Drawdown is provided as an area-averaged value in the corresponding model cell. Drawdown in the well cell reached a maximum depth of $0.98 \mathrm{~m}$ after 40 years of stress. After pumping above baseline rates was stopped, drawdown decreased from 0.98 to $0.13 \mathrm{~m}$ during the 40 years of recovery. The cell regained 87 percent of the pre-stress head.

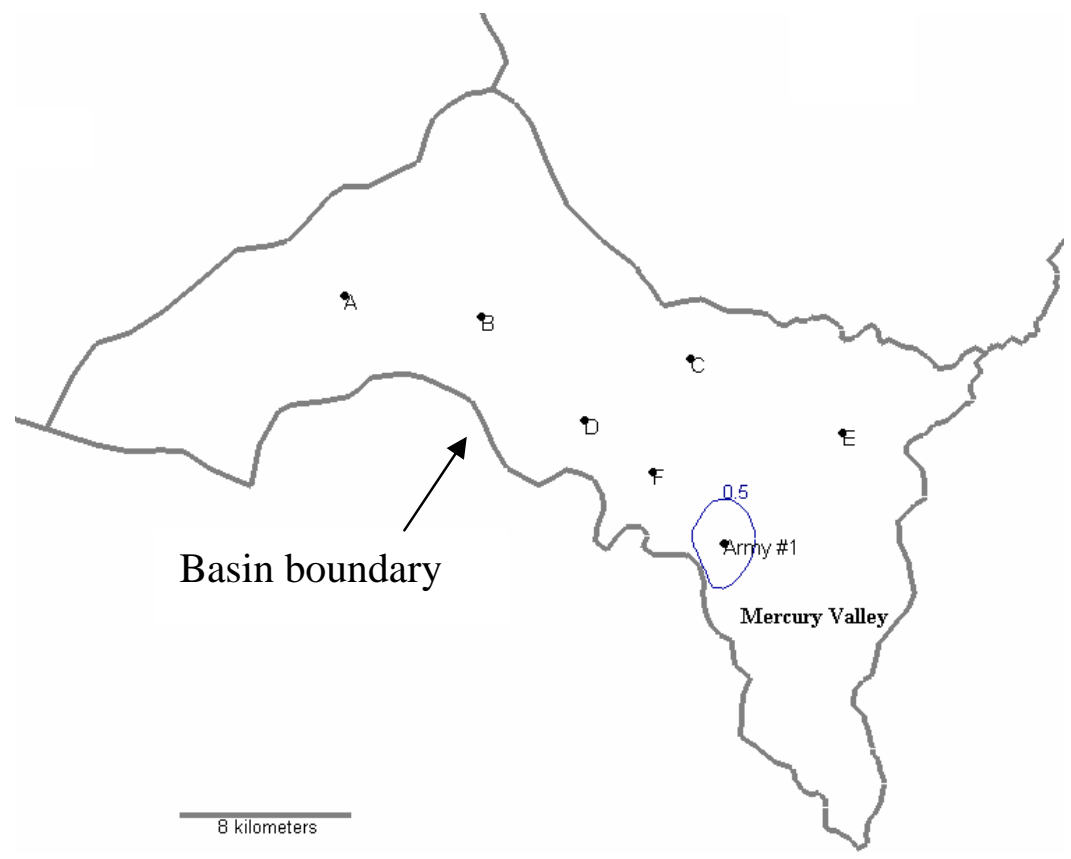

Figure 9. The lateral extent of drawdown in excess of baseline scenario drawdown (model layer 8) in Mercury Valley for the maximum stress scenario with 50 percent of the estimated perennial yield withdrawn from Army \#1 Water Well. Shown is the 0.5-m drawdown contour. 


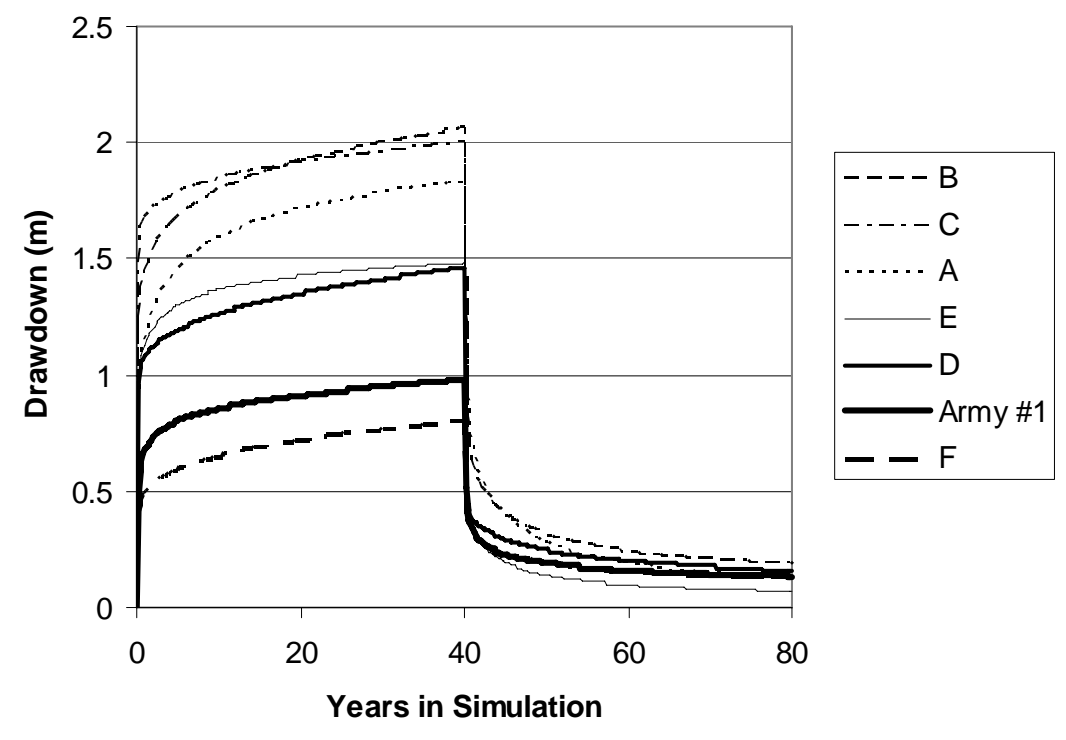

Figure 10. Drawdown within the model cell and recovery of head with respect to time plotted for the seven single well maximum stress pumping scenarios.

Volumetric water-budget information is presented in Table 5. Most of the water for the increased pumping rate came from storage; $12,631 \mathrm{~m}^{3} /$ day was extracted from water available in the rock. Pumping at 50 percent of the perennial yield resulted in negligible (less than one percent) changes in spring flow and southern interbasin flow, but net flow into the model from the western, eastern, and northern specified-head boundaries increased by about $500 \mathrm{~m}^{3} /$ day. Because of the use of constant-head boundaries, decreased flow across these boundaries that may occur because of a finite supply of water from outside the basin is not

Table 5. Volumetric water-budget summaries and percentage change comparison for the MVB flow model between the steady-state scenario and existing Army \#1 Water Well shown $\left(\mathrm{m}^{3} /\right.$ day). The best performing simulation for the stress scenario was summarized.

\begin{tabular}{ccccc}
\hline & Flow Type & Steady-state & Army \#1 Volumetric & Army \#1 \% Change \\
\hline In & Storage & - & $12,630.97$ & $\mathrm{n} / \mathrm{a}$ \\
& Constant Head & $153,699.92$ & $154,186.53$ & 0.32 \\
& Head Dependent & $2,325.54$ & $2,325.60$ & 0.00 \\
& Recharge & $14,649.01$ & $14,649.01$ & 0.00 \\
Out & Total & $170,674.48$ & $183,792.11$ & 7.69 \\
& Storage & - & 0.00 & $\mathrm{n} / \mathrm{a}$ \\
& Constant Head & $76,692.05$ & $76,215.92$ & -0.62 \\
& Wells & - & $14,103.09$ & $\mathrm{n} / \mathrm{a}$ \\
& Springs & $89,561.73$ & $89,414.30$ & -0.16 \\
& Head Dependent & $4,413.60$ & $4,413.58$ & 0.00 \\
& Total & $170,667.38$ & $184,146.89$ & 7.90 \\
\hline
\end{tabular}


being simulated. As stated previously, this boundary type was used because it is the most appropriate choice of the three. A constant flow boundary would result in dry cells if the chosen simulated flow rate was too low and flooded cells if the chosen flow rate was too high. Head-dependent flow boundaries would describe the system more accurately, but these require a conductance and an elevation value and therefore could only be used in three small areas where these values were known. The constant-head boundary was most appropriate since the model domain is large, but results should be evaluated for real-world plausibility.

\section{Hypothetical Well Optimization Simulations}

Hypothetical Well A Maximum Stress Scenario

During the maximum stress simulation of hypothetical Well A, the existing pumping wells in Frenchman Flat, Jackass Flats, and Mercury Valley were continually pumped at 2003-2004 average rates. Pumping from hypothetical Well A could be simulated at a maximum pumping rate of $10,814 \mathrm{~m}^{3} /$ day while limiting drawdown at the basin boundary approximately $0.5 \mathrm{~m}$. This pumping rate corresponds to 40 percent of the perennial yield. Figure 11 shows the $0.5-\mathrm{m}$ and $1.0-\mathrm{m}$ lateral drawdown contours caused by this stress scenario. Drawdown and well recovery as a function of simulation time are shown in Figure 10. After pumping above baseline rates was stopped, drawdown decreased from 1.83 to 0.13 $\mathrm{m}$ during the 40 years of recovery time with 93 percent water-table recovery. Figure 12 shows the lateral drawdown induced when 50 percent of the perennial yield is pumped from hypothetical Well A. The $0.5-\mathrm{m}$ contour line falls slightly outside the groundwater basin's northern boundary, but this may be acceptable for some pumping exercises and provides added data on the area's response to stress.

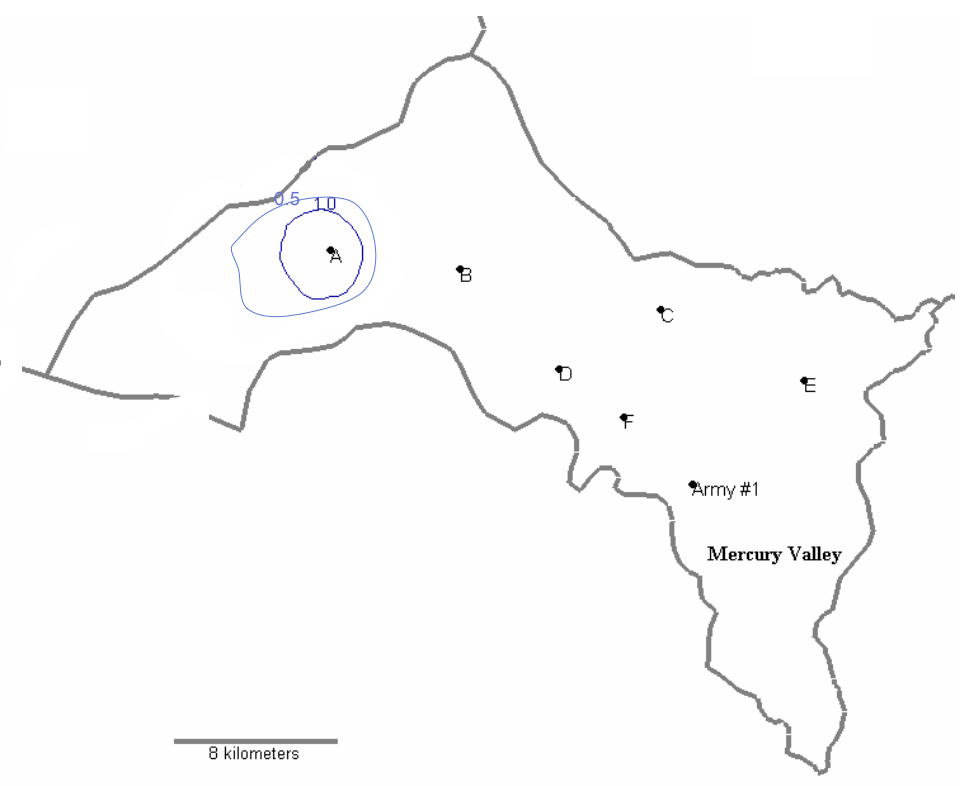

Figure 11. The lateral extent of drawdown for 40 years, model layer 8, in Mercury Valley with 40 percent of the estimated perennial yield withdrawn from hypothetical Well A. Shown are the $0.5-\mathrm{m}$ and $1.0-\mathrm{m}$ drawdown contours. 


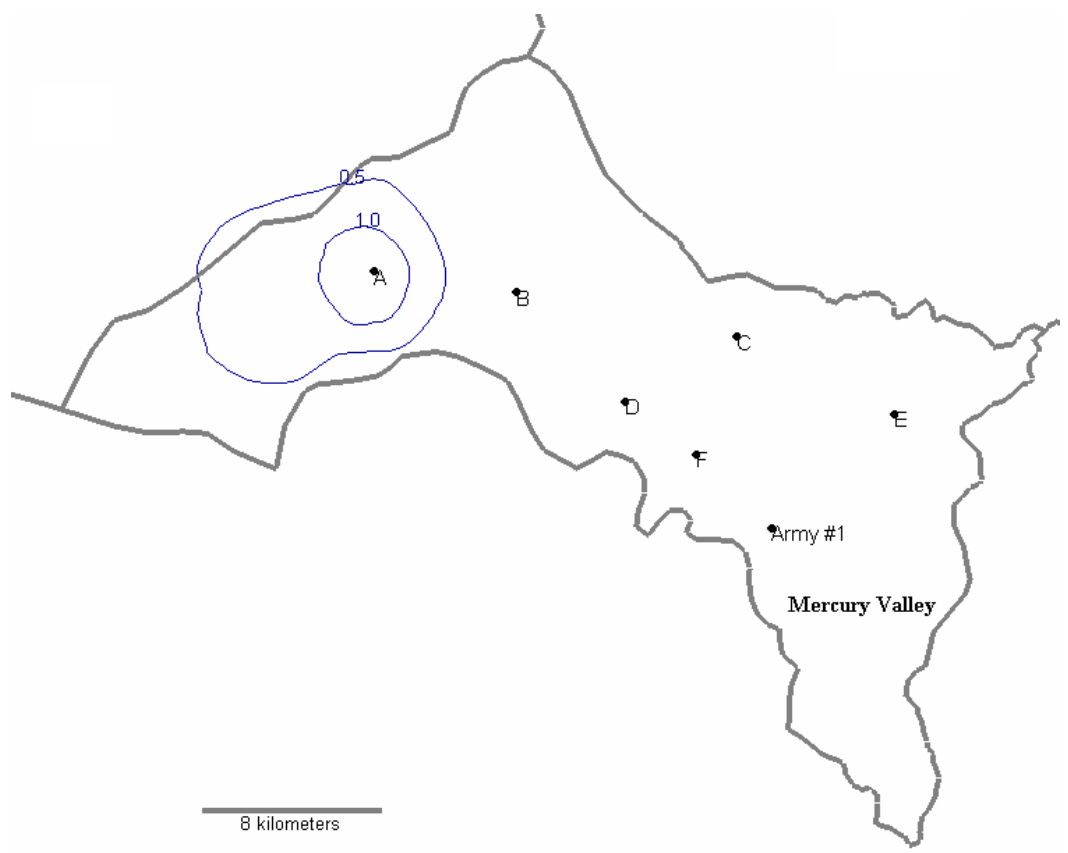

Figure 12. The lateral extent of drawdown for 40 years, model layer 8, in Mercury Valley with 50 percent of the estimated perennial yield withdrawn from hypothetical Well A. Shown are the $0.5-\mathrm{m}$ and $1.0-\mathrm{m}$ drawdown contours.

Water availability in the modeled domain for the hypothetical Well A maximum stress scenario is presented in Table 6. Pumping at 50 percent of the perennial yield resulted in negligible changes $(<1 \%)$ in spring flow, southern interbasin flow, and net flow into the model from the western, eastern, and northern specified-head boundaries. Most of the water for the increased pumping rate came from storage; $13,927 \mathrm{~m}^{3} /$ day was extracted from water available in the rock.

Table 6. Volumetric water-budget summaries and percentage change comparison for the MVB flow model between the steady-state scenario and hypothetical Well A shown ( $\mathrm{m}^{3} /$ day) pumped at 50 percent of the estimated perennial yield.

\begin{tabular}{lcccc}
\hline & Flow Type & Steady-state & Well A Volumetric & Well A \% Change \\
\hline In & Storage & - & $13,927.19$ & n/a \\
& Constant Head & $153,699.92$ & $153,906.78$ & 0.13 \\
& Head Dependent & $2,325.54$ & $2,325.60$ & 0.00 \\
Recharge & $14,649.01$ & $14,649.01$ & 0.00 \\
Total & $170,674.48$ & $184,808.59$ & 8.28 \\
Out & & & n/a \\
& Storage & - & 0.00 & -0.28 \\
& Constant Head & $76,692.05$ & $14,478.05$ & -0.06 \\
Wells & - & $89,506.75$ & 0.00 \\
& Springs & $89,561.73$ & $4,413.58$ & 8.48 \\
\hline
\end{tabular}




\section{Hypothetical Well B Maximum Stress Scenario}

Pumping from hypothetical Well B could be simulated at 90 percent of the perennial yield while honoring drawdown criteria. This corresponds to a daily pumping rate of $24,332 \mathrm{~m}^{3} /$ day while limiting drawdown at the basin boundary to $0.5 \mathrm{~m}$. Figure 13 shows the $0.5-\mathrm{m}$ and $1.0-\mathrm{m}$ lateral drawdown contours caused by this stress scenario. Drawdown and well recovery as a function of simulation time are shown in Figure 10. After pumping above baseline rates was stopped, drawdown decreased from 2.06 to $0.18 \mathrm{~m}$ during the 40 years of recovery time, representing a 91 percent recovery. For comparison, the pumping scenario in which 100 percent of the perennial yield is withdrawn is shown in Figure 14. The 0.5-m drawdown contour extends past the northeastern and southern MVB boundaries slightly, but this may be acceptable in some circumstances.

Water availability in the modeled domain for the hypothetical Well B 100 percent perennial yield stress scenario is presented in Table 7. Pumping at 100 percent of the perennial yield resulted in $25,868 \mathrm{~m}^{3} /$ day extracted from storage. This pumping scenario resulted in negligible changes $(<1 \%)$ in spring flow and southern interbasin flow, but net flow into the model from the western, eastern, and northern specified-head boundaries increased by about $900 \mathrm{~m}^{3} /$ day.

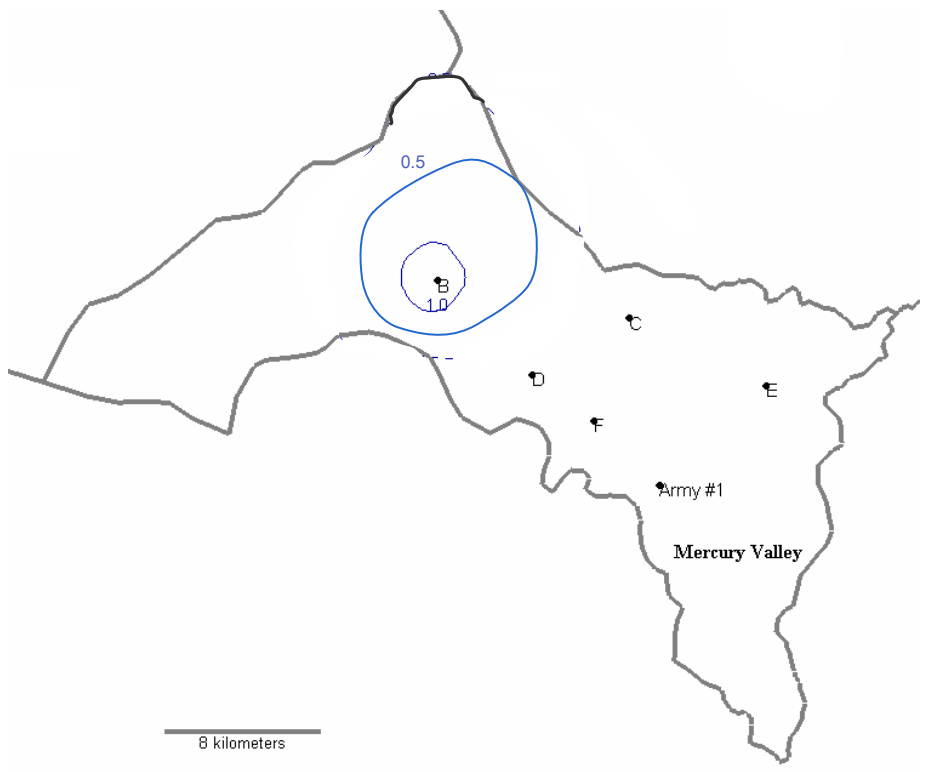

Figure 13. The lateral extent of drawdown for 40 years, model layer 8, in Mercury Valley with 90 percent of the estimated perennial yield withdrawn from hypothetical Well B. Shown are the 0.5 -m and 1.0-m drawdown contours. 


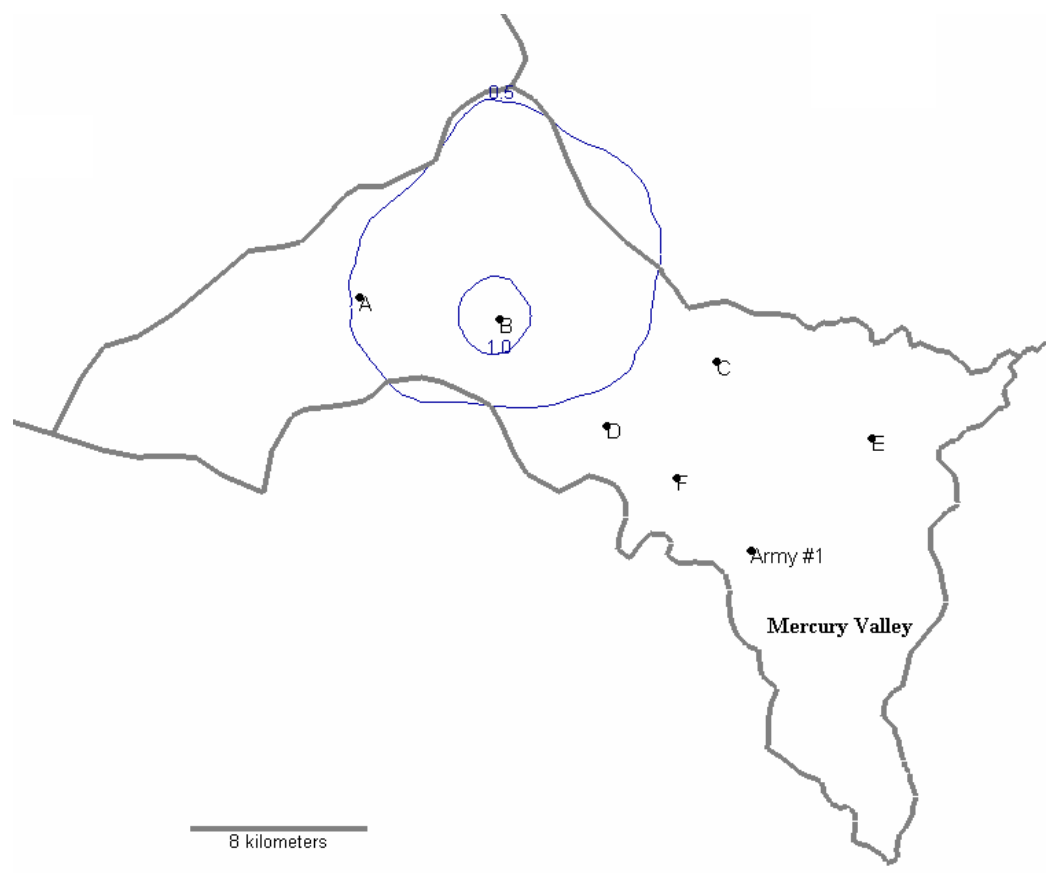

Figure 14. The lateral extent of drawdown for 40 years, model layer 8, in Mercury Valley with 100 percent of the estimated perennial yield withdrawn from hypothetical Well B. Shown are the 0.5 -m and 1.0-m drawdown contours.

Table 7. Volumetric water-budget summaries and percentage change comparison for the MVB flow model between the steady-state scenario and hypothetical Well B shown ( $\mathrm{m}^{3} /$ day). The best performing simulation for the stress scenario was summarized.

\begin{tabular}{ccccc}
\hline & Flow Type & Steady-state & Well B Volumetric & Well B \% Change \\
\hline In & Storage & - & $25,867.53$ & $\mathrm{n} / \mathrm{a}$ \\
& Constant Head & $153,699.92$ & $154,634.92$ & 0.61 \\
& & & & 0.00 \\
& Head Dependent & $2,325.54$ & $2,325.60$ & 0.00 \\
& Recharge & $14,649.01$ & $14,649.01$ & 15.70 \\
Total & $170,674.48$ & $197,477.06$ & $\mathrm{n} / \mathrm{a}$ \\
& & & -1.14 \\
Out & - & 0.00 & $\mathrm{n} / \mathrm{a}$ \\
& Storage & $76,692.05$ & $75,814.34$ & -0.22 \\
& Constant Head & - & $28,267.08$ & 0.00 \\
& Wells & $89,561.73$ & $89,361.10$ & 15.93 \\
\hline Springs & $4,413.60$ & $4,413.58$ & \\
& Head Dependent & $170,667.38$ & $197,856.09$ & \\
Total & 0 & -0.19 &
\end{tabular}

\section{Hypothetical Well C maximum Stress Scenario}

Pumping from hypothetical Well $\mathrm{C}$ could be simulated at a maximum pumping rate of $18,925 \mathrm{~m}^{3} /$ day while limiting drawdown at basin boundaries to $0.5 \mathrm{~m}$. This pumping rate 
corresponds to 70 percent of the perennial yield as defined by Scott et al. (1971). Figure 15 shows the $0.5-\mathrm{m}$ and $1.0-\mathrm{m}$ lateral drawdown contours caused by this stress scenario. Drawdown and well recovery as a function of simulation time are shown in Figure 10. After pumping was stopped, drawdown decreased from 2.0 to $0.12 \mathrm{~m}$ during the 40 years of recovery time, exhibiting 94 percent recovery.

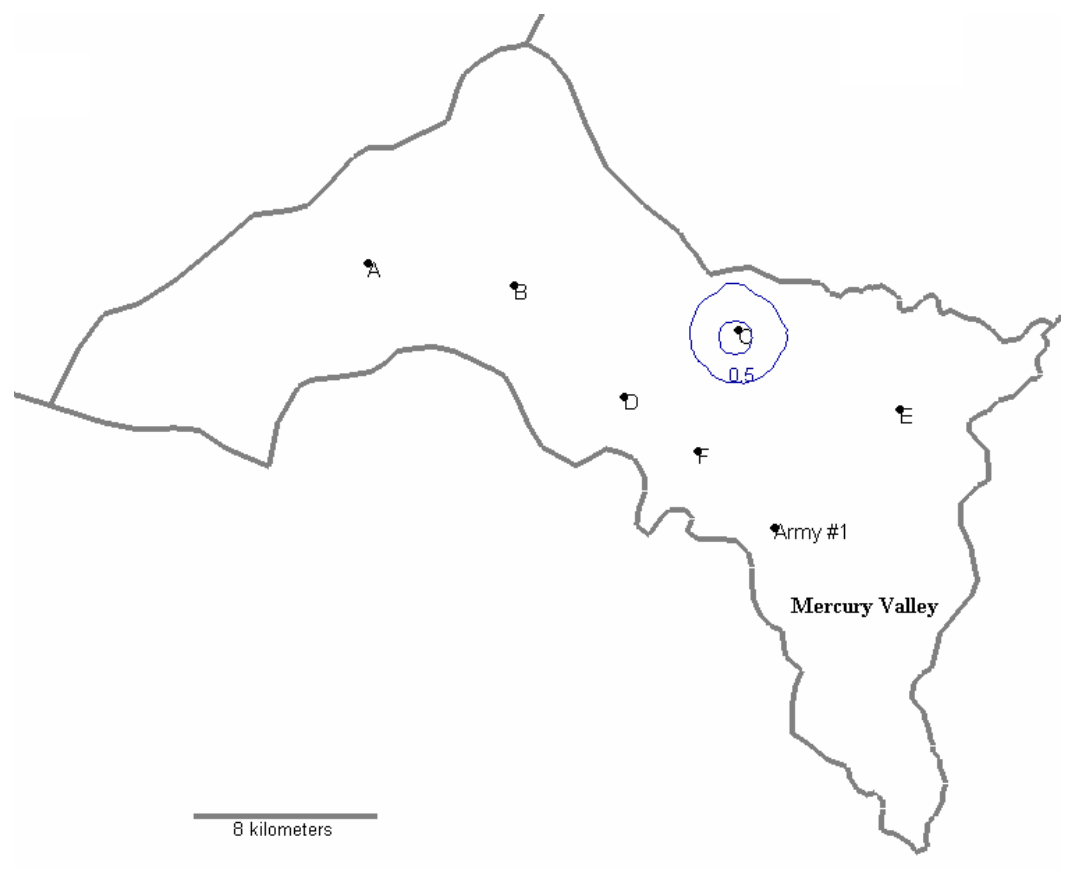

Figure 15. The lateral extent of drawdown for 40 years, model layer 8, in Mercury Valley with 70 percent of the estimated perennial yield withdrawn from hypothetical Well C. Shown are the $0.5-\mathrm{m}$ and 1.0-m drawdown contours.

Water availability in the modeled domain for the hypothetical Well C maximum stress scenario is presented in Table 8. Pumping at 70 percent of the perennial yield resulted in negligible changes $(<1 \%)$ in spring flow and southern interbasin flow, but net flow into the model from the western, eastern, and northern specified-head boundaries increased by about $1,100 \mathrm{~m}^{3} /$ day. Most of the water for the increased pumping rate came from storage; $17,258 \mathrm{~m}^{3} /$ day was extracted from water available in the rock. 
Table 8. Volumetric water-budget summaries and percentage change comparison for the MVB flow model between the steady-state scenario and hypothetical water Well C shown $\left(\mathrm{m}^{3} /\right.$ day). The best performing simulation for the stress scenario was summarized.

\begin{tabular}{lcccc}
\hline & Flow Type & Steady-state & Well C Volumetric & Well C \% Change \\
\hline In & Storage & - & $17,258.00$ & n/a \\
& Constant Head & $153,699.92$ & $154,911.58$ & 0.79 \\
& Head Dependent & $2,325.54$ & $2,325.60$ & 0.00 \\
& Recharge & $14,649.01$ & $14,649.01$ & 0.00 \\
& Total & $170,674.48$ & $189,144.19$ & 10.82 \\
& & & $\mathrm{n} / \mathrm{a}$ \\
Out & - & 0.00 & -1.49 \\
& Storage & $76,692.05$ & $75,550.42$ & $\mathrm{n} / \mathrm{a}$ \\
& Constant Head & - & $20,156.28$ & -0.16 \\
& Wells & $89,561.73$ & $89,421.38$ & 0.00 \\
& Springs & $4,413.60$ & $4,413.58$ & 11.06 \\
\hline & Head Dependent & $170,667.38$ & $189,541.67$ & \\
Total & 0 & -0.21 &
\end{tabular}

Hypothetical Well D Maximum Stress Scenario

Pumping from hypothetical Well D could be simulated at a maximum pumping rate of $21,629 \mathrm{~m}^{3} /$ day while limiting drawdown at the basin boundary to $0.5 \mathrm{~m}$. This pumping rate corresponds to 80 percent of the MVB perennial yield. Figure 16 shows the $0.5-\mathrm{m}$ and $1.0-\mathrm{m}$ lateral drawdown contours caused by this stress scenario. Drawdown and well recovery as a function of simulation time are shown in Figure 10. After pumping was stopped, drawdown decreased from 1.46 to $0.16 \mathrm{~m}$ during the 40 years of recovery time, resulting in 89 percent water-table recovery.

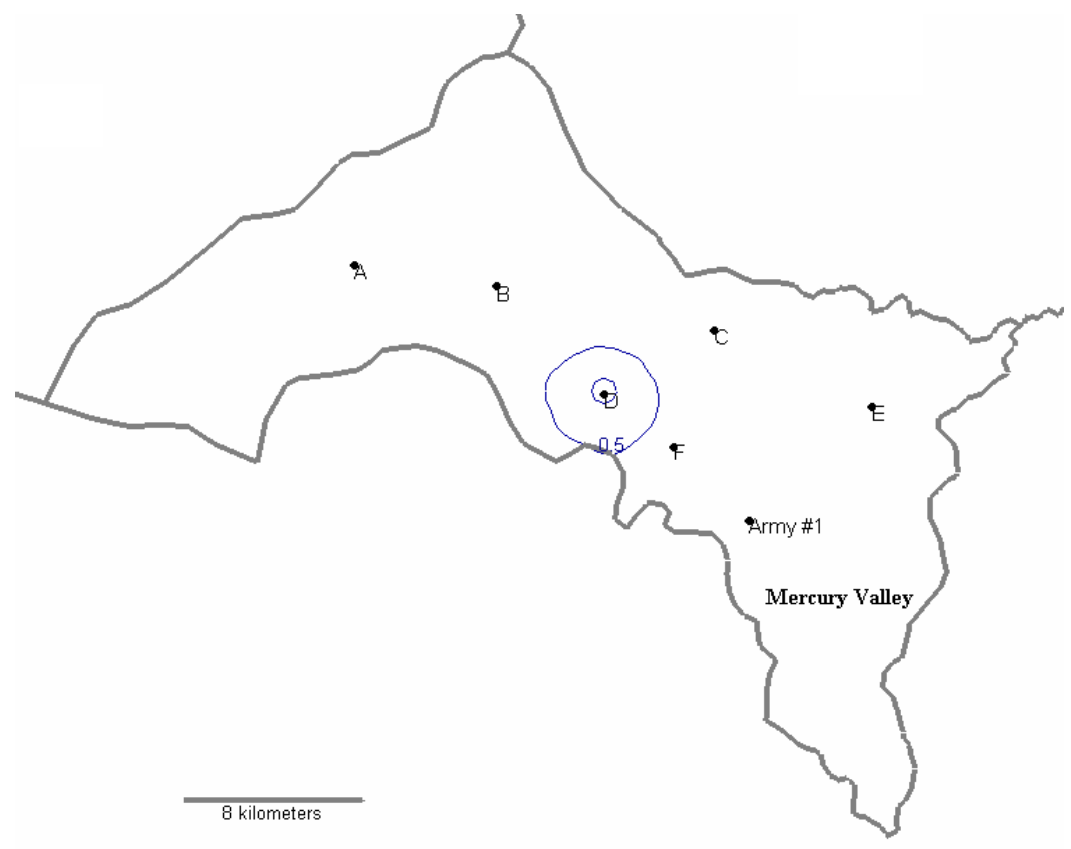

Figure 16. The lateral extent of drawdown for 40 years, model layer 8, in Mercury Valley with 80 percent of the estimated perennial yield withdrawn from hypothetical Well D. Shown are the $0.5-\mathrm{m}$ and $1.0-\mathrm{m}$ drawdown contours. 
The water budget of the modeled domain for the hypothetical Well D maximum stress scenario is presented in Table 9. Continually pumping at 80 percent of the perennial yield resulted in negligible changes $(<1 \%)$ in spring flow and southern interbasin flow, but net flow into the model from the western, eastern, and northern specified-head boundaries increased by about $750 \mathrm{~m}^{3} /$ day. The majority of the increased flow (20,663 $\mathrm{m}^{3} /$ day) came from storage.

Table 9. Volumetric water-budget summaries and percentage change comparison for the MVB flow model between the steady-state scenario and hypothetical water Well D shown $\left(\mathrm{m}^{3} /\right.$ day). The best performing simulation for the stress scenario was summarized.

\begin{tabular}{|c|c|c|c|c|}
\hline & Flow Type & Steady-state & Well D Volumetric & Well D \% Change \\
\hline \multirow[t]{5}{*}{ In } & Storage & - & $20,662.97$ & $\mathrm{n} / \mathrm{a}$ \\
\hline & Constant Head & $153,699.92$ & $154,486.84$ & 0.51 \\
\hline & Head Dependent & $2,325.54$ & $2,325.60$ & 0.00 \\
\hline & Recharge & $14,649.01$ & $14,649.01$ & 0.00 \\
\hline & Total & $170,674.48$ & $192,124.42$ & 12.57 \\
\hline \multirow[t]{7}{*}{ Out } & Storage & - & 0.00 & $\mathrm{n} / \mathrm{a}$ \\
\hline & Constant Head & $76,692.05$ & $75,939.61$ & -0.98 \\
\hline & Wells & & $22,859.88$ & $\mathrm{n} / \mathrm{a}$ \\
\hline & Springs & $89,561.73$ & $89,315.65$ & -0.27 \\
\hline & Head Dependent & $4,413.60$ & $4,413.58$ & 0.00 \\
\hline & Total & $170,667.38$ & $192,528.70$ & 12.81 \\
\hline & \% discrepancy & 0 & -0.21 & \\
\hline
\end{tabular}

\section{Hypothetical Well E Maximum Stress Scenario}

Hypothetical Well E could be simulated to pump at 50 percent of MVB's perennial yield while limiting drawdown at the basin boundary to $0.5 \mathrm{~m}$. This corresponds to a daily pumping rate of $13,518 \mathrm{~m}^{3}$. Figure 17 shows the $0.5-\mathrm{m}$ and $1.0-\mathrm{m}$ lateral drawdown contours caused by this stress scenario. Drawdown and well recovery as functions of simulation time are shown in Figure 10. After pumping above baseline rates was stopped, drawdown decreased from 1.49 to $0.07 \mathrm{~m}$ during the 40 years of recovery time, exhibiting 95 percent recovery of water-table elevation. 


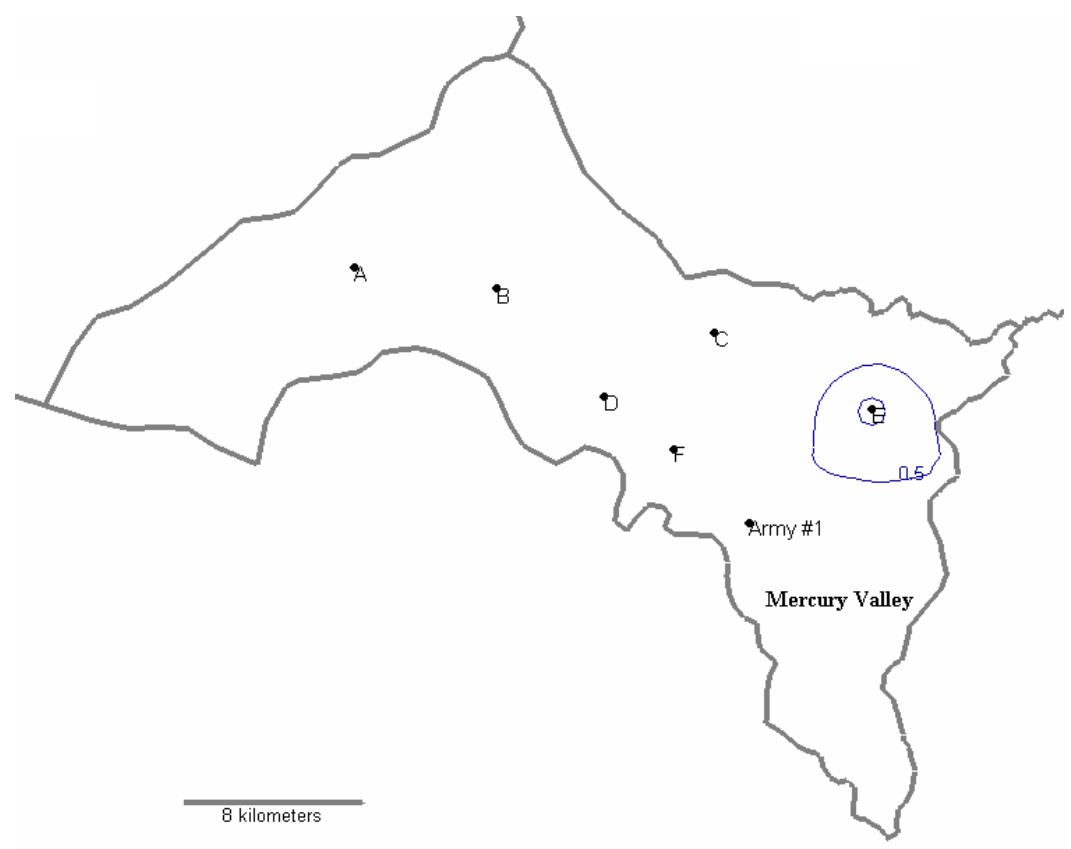

Figure 17. The lateral extent of drawdown for 40 years, model layer 8, in Mercury Valley with 50 percent of the estimated perennial yield withdrawn from hypothetical Well E. Shown are the $0.5-\mathrm{m}$ and $1.0-\mathrm{m}$ drawdown contours.

The water budget for the modeled domain under the hypothetical Well E maximum stress scenario is presented in Table 10. Pumping at 50 percent of the perennial yield resulted in negligible changes $(<1 \%)$ in spring flow and southern interbasin flow. Net flow into the model from the western, eastern, and northern specified-head boundaries increased by about $1,500 \mathrm{~m}^{3} /$ day. The lowest percentage of water extracted from storage relative to other sources was in this simulation; 11,238 $\mathrm{m}^{3}$ /day were extracted at hypothetical Well E.

Table 10. Volumetric water-budget summaries and percentage change comparison for the MVB flow model between the steady-state scenario and hypothetical water Well E shown $\left(\mathrm{m}^{3} /\right.$ day). The best performing simulation for the stress scenario was summarized.

\begin{tabular}{ccccc}
\hline & Flow Type & Steady-state & Well E Volumetric & Well E \% Change \\
\hline In & Storage & - & $11,237.98$ & n/a \\
& Constant Head & $153,699.92$ & $155,299.81$ & 1.04 \\
& Head Dependent & $2,325.54$ & $2,325.60$ & 0.00 \\
& Recharge & $14,649.01$ & $14,649.01$ & 0.00 \\
& Total & $170,674.48$ & $183,512.41$ & 7.52 \\
& & & \\
\multirow{4}{*}{ Out } & - & 0.00 & $\mathrm{n} / \mathrm{a}$ \\
& Storage & $76,692.05$ & $75,218.84$ & -1.92 \\
& Constant Head & - & $14,749.08$ & $\mathrm{n} / \mathrm{a}$ \\
& Wells & $89,561.73$ & $89,504.16$ & -0.06 \\
& Springs & $4,413.60$ & $4,413.58$ & 0.00 \\
& Head Dependent & $170,667.38$ & $183,885.66$ & 7.75 \\
\hline Total & 0 & -0.2 & \\
\hline
\end{tabular}


Hypothetical Well F Maximum Stress Scenario

Pumping from hypothetical Well F could be simulated at a maximum pumping rate of $16,222 \mathrm{~m}^{3}$ /day while limiting drawdown at the basin boundary to $0.5 \mathrm{~m}$. This pumping rate corresponds to 60 percent of the perennial yield as defined by Scott et al. (1971). Figure 18 shows the 0.5 -m and 1.0-m lateral drawdown contours caused by this stress scenario. Although hypothetical Well F had the highest hydraulic conductivity of the hypothetical wells, its proximity to the groundwater basin boundary and the high conductivity zone to the southwest resulted in a relatively low maximum pumping rate. Drawdown from baseline pumping of Army \#1 Water Well may have also affected the pumping capability of this well site.

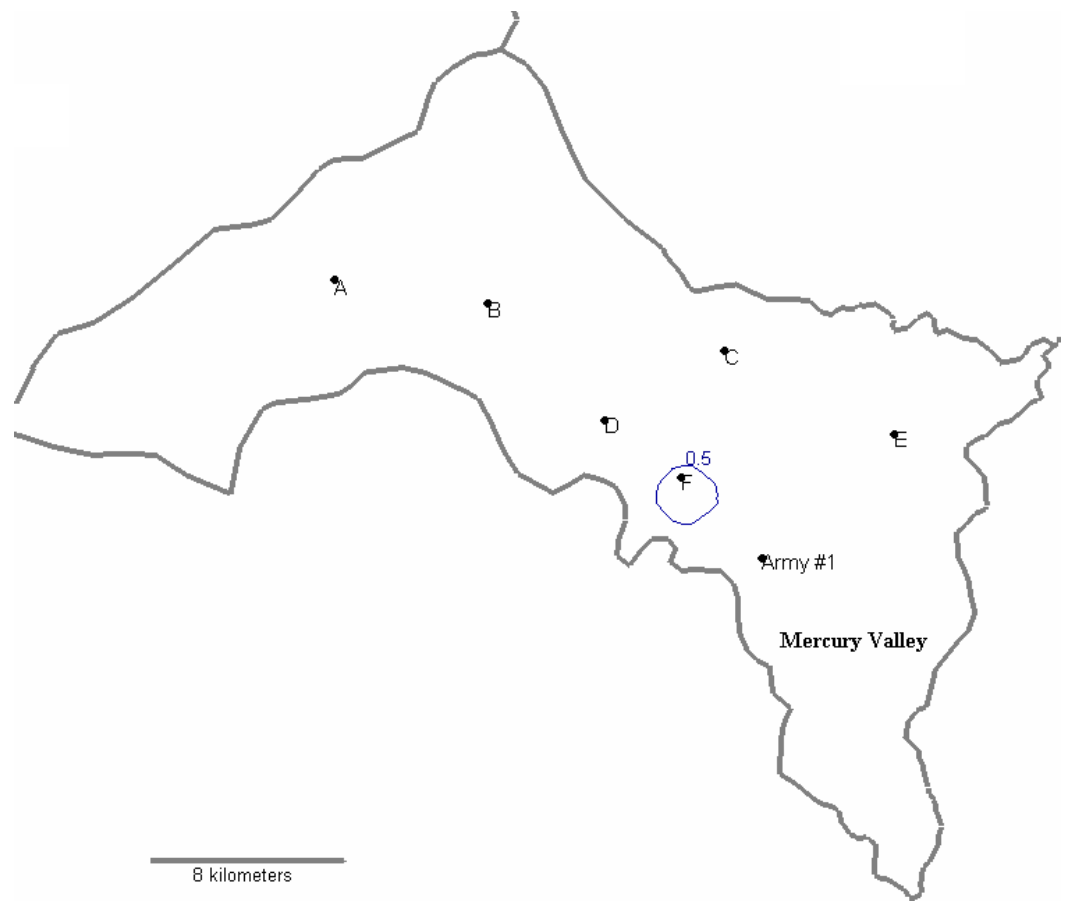

Figure 18. The lateral extent of drawdown after 40 years, model layer 8, in Mercury Valley with 60 percent of the estimated perennial yield withdrawn from hypothetical Well F. Shown is the 0.5-m drawdown contour.

Drawdown and well recovery as functions of simulation time are shown in Figure 10. Once pumping above baseline rates ceased, drawdown decreased from 0.80 to $0.13 \mathrm{~m}$ during the 40 years of recovery time. This corresponds to 84 percent water-table recovery. Also shown is the stress scenario in which 70 percent of the perennial yield is pumped. As can be seen in Figure 19, the 0.5-m contour line is much larger and has moved significantly to the south and west. This may be because of the high hydraulic conductivity in this area.

Water availability to the hypothetical Well F maximum stress scenario is presented in Table 11. Pumping at 60 percent of the perennial yield resulted in negligible $(<1 \%)$ changes in spring flow and southern interbasin flow. Net flow into the model from the western, eastern, and northern specified-head boundaries increased by about $600 \mathrm{~m}^{3} / \mathrm{day}$, and $15,704 \mathrm{~m}^{3}$ /day were extracted from storage. 


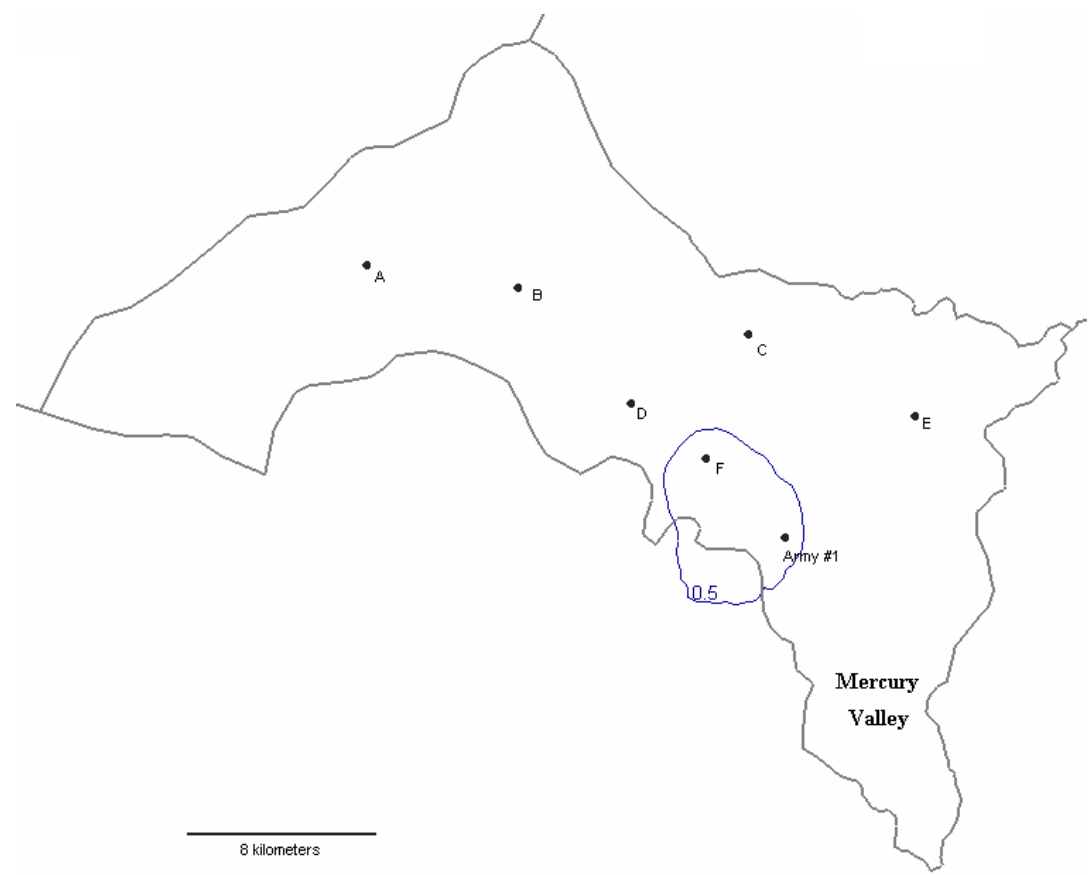

Figure 19. The lateral extent of drawdown after 40 years, model layer 8, in Mercury Valley with 70 percent of the estimated perennial yield withdrawn from hypothetical Well F. Shown is the 0.5-m drawdown contour.

Table 11. Volumetric water-budget summaries and percentage change comparison for the MVB flow model between the steady-state scenario and hypothetical water Well F shown ( $\mathrm{m}^{3} /$ day). The best performing simulation for the stress scenario was summarized.

\begin{tabular}{ccccc}
\hline & Flow Type & Steady-state & Well F Volumetric & Well F \% Change \\
\hline In & Storage & - & $15,704.40$ & $\mathrm{n} / \mathrm{a}$ \\
& Constant Head & $153,699.92$ & $154,309.94$ & 0.40 \\
& Head Dependent & $2,325.54$ & $2,325.60$ & 0.00 \\
Recharge & $14,649.01$ & $14,649.01$ & 0.00 \\
& Total & $170,674.48$ & $186,988.95$ & 9.56 \\
& & & \\
& Storage & - & 0.00 & $\mathrm{n} / \mathrm{a}$ \\
& Constant Head & $76,692.05$ & $76,102.16$ & -0.77 \\
& Wells & - & $17,453.08$ & $\mathrm{n} / \mathrm{a}$ \\
& Springs & $89,561.73$ & $89,372.22$ & -0.21 \\
& $4,413.60$ & $4,413.58$ & 0.00 \\
& Head Dependent & $170,667.38$ & $187,341.03$ & 9.77 \\
& Total & 0 & -0.19 & \\
\hline
\end{tabular}


Hypothetical Multiple Well Maximum Stress Scenario

In the multiple well scenario, existing pumping wells in Frenchman Flat, Jackass Flats, and Mercury Valley were continually pumped at the 2003-2004 average rates. Hypothetical Wells A, B, C, D, E, and F were simultaneously pumped at 4,506 $\mathrm{m}^{3} /$ day. The combined pumping rate of $27,036 \mathrm{~m}^{3} /$ day is equal to the perennial yield defined for Mercury Valley. Since the average pumping rate during 2003-2004 for Army \#1 Water Well was only $646 \mathrm{~m}^{3} /$ day, it was allowed to remain pumping, although this additional withdrawal resulted in pumping slightly more than the perennial yield. This stress scenario provided a way to compare well performance at reduced pumping rates with several withdrawal locations. A combination of two or more pumping wells in operation would be the best way to achieve maximum groundwater withdrawal at most locations within Mercury Valley.

A numerical experiment was performed in which the screened interval of hypothetical wells A through $\mathrm{F}$ was moved upward to model layers 7 and 8 , as opposed to the original location of the screened interval in model layers 8 and 9 . The pumping rate of $4,506 \mathrm{~m}^{3} /$ day in all wells was maintained. The new screened interval corresponds to a top elevation of $900 \mathrm{~m}$ above mean sea level. The run was not successful since several of the hypothetical wells were pumped dry during the 40 -year stress period. The pumping scenario in which the screened interval was in layers 8 and 9, corresponding to a top elevation of $800 \mathrm{~m}$ above mean sea level, was successful, just as it had been in each of the single well maximum stress scenarios.

Groundwater pumping could be simulated at the perennial yield while easily staying within drawdown guidelines established for the study. Figure 20 shows the $0.5-\mathrm{m}$ lateral drawdown contours caused by this stress scenario. Drawdown and recovery of each well as functions of simulation time are shown in Figure 21. Maximum drawdown at each location was less than $0.9 \mathrm{~m}$. Within the cell containing Well $\mathrm{C}$, maximum drawdown was only about $0.5 \mathrm{~m}$. This drawdown is not representative of the drawdown within the well, since it is spread over the entire cell surface area of $0.64 \mathrm{~km}^{2}$. The drawdown curves are steeper at the end of the pumping phase in the multiple well scenario than in the single well pumping scenarios. This may be because of the effect of separate drawdown cones beginning to coincide with one another and increasing the rate of water-table drawdown.

Water availability in the modeled domain for the hypothetical six-well pumping stress scenario may be evaluated by examining withdrawal rates, areal extent of drawdown, and corresponding changes to the volumetric water budgets between the steady-state and the stressed simulations. Volumetric water-budget information is presented in Table 12. Pumping 100 percent of the perennial yield from the six wells resulted in negligible changes $(<1 \%)$ in spring flow and southern interbasin flow, but net flow into the model from the western, eastern, and northern specified-head boundaries increased by about $1,300 \mathrm{~m}^{3} /$ day. The majority of flow (almost 25,000 $\mathrm{m}^{3} /$ day) came from storage. 


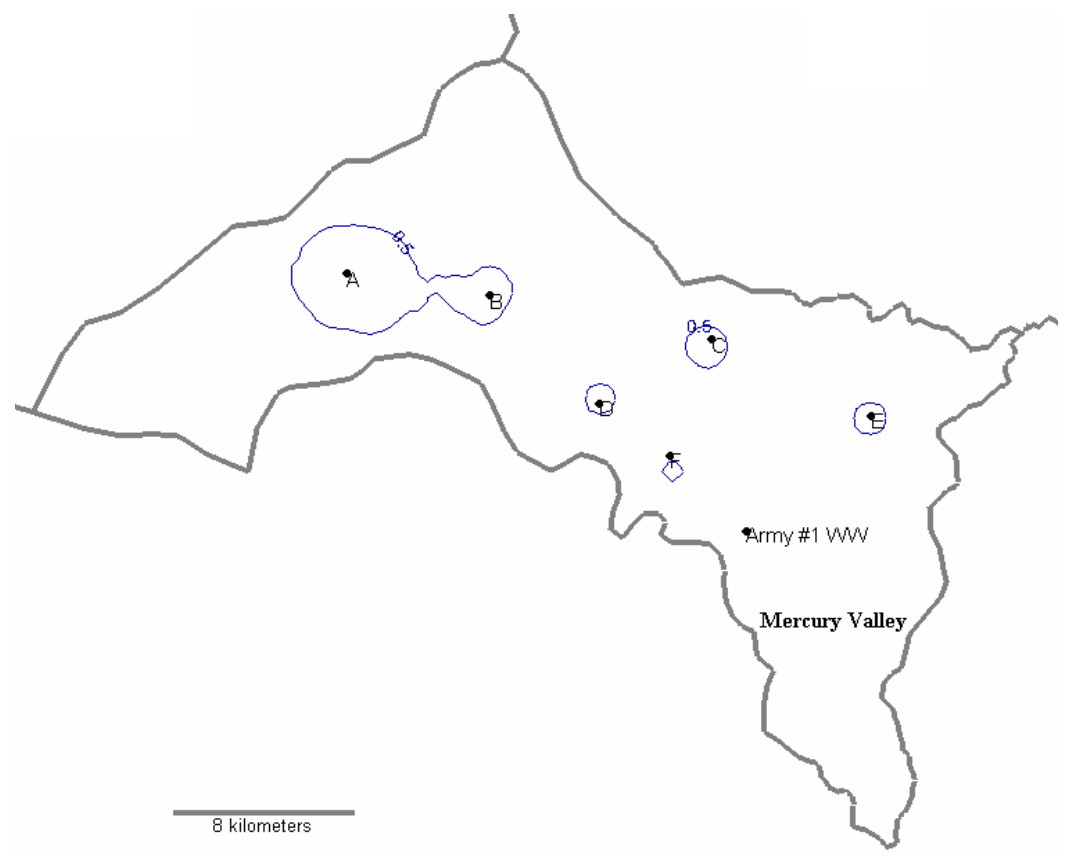

Figure 20. The lateral extent of drawdown after 40 years, model layer 8, in Mercury Valley with hypothetical wells A through F collectively pumping perennial yield. Wells A through $\mathrm{F}$ each withdraw $4,506 \mathrm{~m}^{3} /$ day. Shown is the $0.5-\mathrm{m}$ drawdown contour.

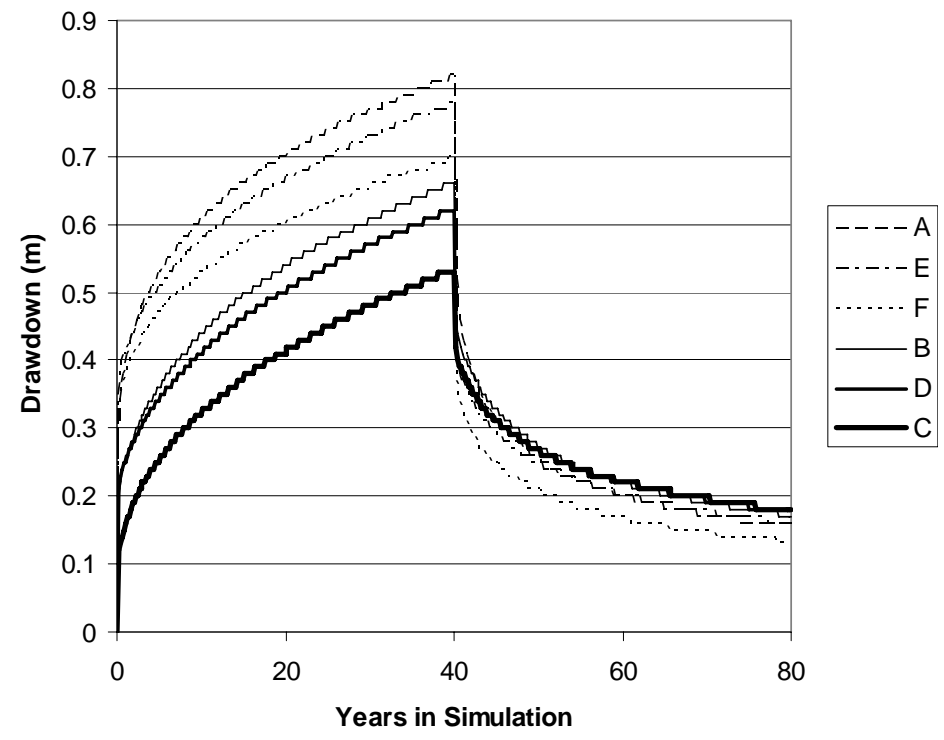

Figure 21. Drawdown and recovery with respect to time plotted for theoretical wells A through F, each simultaneously pumping one-sixth of the perennial yield. 
Table 12. Volumetric water-budget summaries and percentage change comparison for the MVB flow model between the steady-state scenario and the six hypothetical well pumping scenario shown ( $\mathrm{m}^{3} /$ day). The simulation pumped each hypothetical well at $4,506 \mathrm{~m}^{3} /$ day (one-sixth of the perennial yield of Mercury Valley).

\begin{tabular}{ccccc}
\hline & Flow Type & Steady-state & Six Well Volumetric & Six Well \% Change \\
\hline In & Storage & - & $24,939.07$ & $\mathrm{n} / \mathrm{a}$ \\
& Constant Head & $153,699.92$ & $155,083.17$ & 0.90 \\
& Head Dependent & $2,325.54$ & $2,325.60$ & 0.00 \\
Recharge & $14,649.01$ & $14,649.01$ & 0.00 \\
& Total & $170,674.48$ & $196,996.84$ & 15.42 \\
& & & \\
\multirow{4}{*}{ Out } & - & 0.00 & $\mathrm{n} / \mathrm{a}$ \\
& Storage & $76,692.05$ & $75,398.76$ & -1.69 \\
& Constant Head & - & $28,267.08$ & $\mathrm{n} / \mathrm{a}$ \\
& Wells & $89,561.73$ & $89,356.69$ & -0.23 \\
& Springs & $4,413.60$ & $4,413.58$ & 0.00 \\
& Head Dependent & $170,667.38$ & $197,436.09$ & 15.68 \\
\hline Total & 0 & -0.22 & \\
\hline
\end{tabular}

\section{Thiem Drawdown Corrections}

Drawdown depths in MODFLOW cells with pumping wells have been reported for each pumping well stress simulation. The drawdown value reported represents the head loss averaged over the entire area of the well-containing cell, an area of $0.64 \mathrm{~km}^{2}$. In reality, head elevation decrease from drawdown peaks at the well bore and abates with distance from the well. To get a more accurate estimate of the drawdown at the well bore, the Thiem Equation was used to approximate the increase in drawdown from the cell edge to the well bore contained in the cell.

The Thiem Equation for calculating drawdown at the top of the well bore inside a confined cell is (Anderson and Woessner, 1992)

$$
h_{w}=h_{\text {cell }}-\frac{Q_{\text {cell }}}{2 \pi T_{\text {cell }}} \ln \left(\frac{r_{e}}{r_{w}}\right)
$$

where $h_{w}$ is the head in the well bore [L], $h_{\text {cell }}$ is the simulated head as computed by MODFLOW of the cell in which the well is contained [L], $Q_{\text {cell }}$ is the volumetric flow rate to the well from the layer containing the cell $\left[\mathrm{L}^{3} / \mathrm{T}\right], T_{\text {cell }}$ is the transmissivity of the cell $\left[\mathrm{L}^{2} / \mathrm{T}\right]$, $r_{e}$ is the effective radial distance from the cell node to the cell edge [L], and $r_{w}$ is the radius of the interior of the well [L]. The diameter of the well was chosen to be $30 \mathrm{~cm}$, a reasonable diameter for a large water-supply well.

For three-dimensional flow models, hydraulic head, volumetric flow rate, and transmissivity values of only the cell containing the top of the screened interval are used to estimate well bore drawdown. Flow from the aquifer is assumed to be independent of direction, forming a radial drawdown cone. The equation also assumes that conditions are steady state, so that flow from storage near the well is assumed to be negligible. 
For a grid with regular grid spacing in the vicinity of the well (Prickett, 1967)

$$
r_{e}=0.208 a_{\text {cell }}
$$

where $r_{e}$ is the effective cell radius [L] and $a_{\text {cell }}$ is the length of the side of the cell [L]. Transmissivity is calculated using the saturated thickness and hydraulic conductivity of the MODFLOW cell

$$
T_{\text {cell }}=K_{\text {cell }} b_{\text {cell }}
$$

where $T_{\text {cell }}$ is the transmissivity of the MODFLOW cell containing the well [ $\left.\mathrm{L}^{2} / \mathrm{T}\right], K_{\text {cell }}$ is the hydraulic conductivity of the cell [L/T], and $b_{\text {cell }}$ is the saturated thickness of the cell [L].

Table 13 shows that corrected drawdown ranges from 2.50 to $5.13 \mathrm{~m}$ for the Mercury Valley maximum stress scenario and the six individual hypothetical well maximum stress scenarios. This results in hydraulic-head elevations ranging between approximately 723 and $725 \mathrm{~m}$ above mean sea level. The uppermost screened interval of Army \#1 Water Well is from 641.3 to $687.3 \mathrm{~m}$ above mean sea level. The screened intervals of the hypothetical wells are from 500 to $700 \mathrm{~m}$ above mean sea level. Even with the larger drawdowns estimated using the Thiem Equation, hydraulic head does not dip below the top of the screened interval of Army \#1 Water Well or any of the hypothetical wells, satisfying the second criterion of the study.

Table 13. Table shows the head at each well before stress simulations began, the head calculated for the cell by MODFLOW where any drawdown is averaged across the cell area, the head calculated using the Thiem Equation to approximate the drawdown in the well bore, and corrected drawdown measured as the head difference at the well at baseline conditions and after the stress simulations.

\begin{tabular}{ccccc}
\hline Water Well & $\begin{array}{c}\text { Steady-state Head } \\
(\mathrm{m})\end{array}$ & $\begin{array}{c}\text { Cell-averaged Head } \\
(\mathrm{m})\end{array}$ & $\begin{array}{c}\text { Thiem-corrected Head } \\
(\mathrm{m})\end{array}$ & Drawdown (m) \\
\hline Army & 727.13 & 726.15 & 722.66 & 4.47 \\
A & 726.58 & 724.75 & 723.56 & 3.02 \\
B & 727.39 & 725.33 & 722.82 & 4.57 \\
C & 727.87 & 725.87 & 722.74 & 5.13 \\
D & 727.08 & 725.62 & 723.15 & 3.93 \\
E & 728.86 & 727.37 & 724.94 & 3.92 \\
F & 727.09 & 726.29 & 724.59 & 2.50 \\
\hline
\end{tabular}

\section{Transient Results Summary}

\section{Baseline Stress Scenario}

- Baseline withdrawal rates for each existing pumping well were derived from the average monthly withdrawals from July 2003 to July 2004.

- Maximum drawdown was $13.9 \mathrm{~m}$ in Water Well 5C.

- Wellbore drawdown was negligible in Army \# 1 Water Well.

- Drawdown was contained within each well's groundwater basin. 


\section{Mercury Valley Maximum Stress Scenario}

- Existing water-supply wells J-12, J-13, 5B, and 5C were pumped for the entire 80-year simulation period at 2003-2004 baseline rates.

- Existing Army \#1 Water Well could be pumped at 50 percent perennial yield $\left(13,518 \mathrm{~m}^{3} /\right.$ day $)$.

- Army \#1 Water Well continued to be pumped at 2003-2004 baseline rates after the 40 year stress period.

- Maximum pumping rate was limited because of its proximity to the MVB boundary.

- Maximum drawdown in Army \#1 Water Well was less than $1 \mathrm{~m}$ after 40 years of pumping.

- Drawdown recovery was 87 percent after 40 years.

- Pumping resulted in negligible changes to spring flow and interbasin flow at the southern boundary.

- Flow into the western, eastern, and northern specified-head boundaries increased by $500 \mathrm{~m}^{3} /$ day.

Hypothetical Well Maximum Stress Scenarios

- Existing water-supply wells J-12, J-13, 5B, 5C, and Army \#1 were pumped for the entire 80-year simulation period at 2003-2004 baseline rates.

- Pumping resulted in negligible changes to spring flow and interbasin flow at the southern boundary.

Hypothetical Well A

- Hypothetical Well A could be pumped at nearly 50 percent perennial yield $\left(13,518 \mathrm{~m}^{3} /\right.$ day $)$.

- Maximum drawdown at the well was less than $2 \mathrm{~m}$ after 40 years of pumping.

- Drawdown recovery was 93 percent after 40 years.

- Pumping resulted in negligible changes to flow into the western, eastern, and northern specified-head boundaries.

Hypothetical Well B

- Hypothetical Well B could be pumped at nearly 100 percent perennial yield $\left(27,036 \mathrm{~m}^{3} /\right.$ day $)$.

- Maximum drawdown at the well was slightly more than $2 \mathrm{~m}$ after 40 years of pumping.

- Drawdown recovery was 91 percent after 40 years.

- Pumping resulted in increased flow into the western, eastern, and northern specifiedhead boundaries by $900 \mathrm{~m}^{3} /$ day.

\section{Hypothetical Well C}

- Hypothetical Well C could be pumped at 70 percent perennial yield $\left(18,925 \mathrm{~m}^{3} /\right.$ day).

- Maximum pumping rate was limited because of its proximity to the MVB boundary.

- Maximum drawdown at the well was $2 \mathrm{~m}$ after 40 years of pumping.

- Drawdown recovery was 94 percent after 40 years. 
- Pumping resulted in increased flow into the western, eastern, and northern specified-head boundaries by $1,100 \mathrm{~m}^{3} /$ day.

\section{Hypothetical Well D}

- Hypothetical Well D could be pumped at 80 percent perennial yield (21,629 $\mathrm{m}^{3} /$ day).

- Maximum pumping rate was limited because of its proximity to the MVB boundary.

- Maximum drawdown at the well was slightly less than $1.5 \mathrm{~m}$ after 40 years of pumping.

- Drawdown recovery was 89 percent after 40 years.

- Pumping resulted in increased flow into the western, eastern, and northern specified-head boundaries by $750 \mathrm{~m}^{3} /$ day.

\section{Hypothetical Well E}

- Hypothetical Well E could be pumped at 50 percent perennial yield (13,518 $\left.\mathrm{m}^{3} / \mathrm{day}\right)$.

- Maximum pumping rate was limited because of its proximity to the MVB boundary.

- Maximum drawdown at the well was $1.5 \mathrm{~m}$ after 40 years of pumping.

- Drawdown recovery was 95 percent after 40 years.

- Pumping resulted in increased flow into the western, eastern, and northern specifiedhead boundaries by $1,500 \mathrm{~m}^{3} /$ day.

Hypothetical Well F

- Hypothetical Well F could be pumped at 60 percent perennial yield (16,222 $\mathrm{m}^{3} /$ day).

- Maximum pumping rate was limited because of its proximity to the MVB boundary.

- Maximum drawdown at the well was less than $1 \mathrm{~m}$ after 40 years of pumping.

- Drawdown recovery was 84 percent after 40 years.

- Pumping resulted in increased flow into the western, eastern, and northern specified-head boundaries by $600 \mathrm{~m}^{3} /$ day.

Multiple Well Maximum Stress Scenario

- Each of the six hypothetical wells was pumped at one-sixth of the perennial yield (4,506 $\mathrm{m}^{3} /$ day).

- Cumulative pumping rate equal to perennial yield was achieved.

- Lateral drawdown was confined to the MVB boundary.

- Maximum drawdown at well locations ranged from 0.53 to $0.82 \mathrm{~m}$.

- Pumping resulted in increased flow into the western, eastern, and northern specified-head boundaries by $1,300 \mathrm{~m}^{3} /$ day.

\section{CONCLUSIONS}

Established drawdown criteria for the study limited lateral drawdown to $0.5 \mathrm{~m}$ or less at the boundary of the MVB and water-table elevation in the cell containing the well to above the elevation of the top of the well's open interval. The maximum stress simulations performed for the MVB show that significant groundwater withdrawals can be obtained from much of the basin. Hypothetical Well B is the only simulated well that was capable of pumping virtually 100 percent of the perennial yield while not violating the stated drawdown criteria. None of the cells containing the top of a pumping well open interval went dry during 
simulation. Because of the large size of model cells, however, the Thiem Equation was used to more accurately estimate the drawdown at the well bore. This equation resulted in drawdowns of approximately 2.5 to $5 \mathrm{~m}$, still leaving 21 to $25 \mathrm{~m}$ between the hydraulic-head elevation and the top of the screened interval. Depending on the needs of the facilities to be sited, two or more wells with significant space between them may be the most practical means of extracting large amounts of groundwater.

Simulated hydraulic conductivity varies over several orders of magnitude with values ranging from nearly $0 \mathrm{~m}$ /day up to $250 \mathrm{~m}$ /day (see Figure 6). However, large uncertainty is associated with hydraulic conductivity since it is one of the least well known parameters in the MVB model. The low number of wells in the area results in a lack of spatially variable aquifer-test data and rock samples. Hydraulic conductivity values are also subject to errors in measurement, subjectivity in analysis, well construction flaws, and other quantifiable influences. The IT Corporation (1996) cites zero percent difference in literature and verified transmissivity values for Army \#1 Water Well, but 70 percent difference between literature and verified transmissivity for a nearby test well.

Despite uncertainty associated with hydraulic conductivity, fluxes from headdependent boundary cells where underflow occurs compared well to target flux ranges. Target flux rate for the head-dependent boundary cells was between 1,600 and 6,750 $\mathrm{m}^{3} / \mathrm{day}$. The MVB flow model simulated head-dependent fluxes within this range during each stress scenario. Spring discharge in the Ash Meadows wetland area decreased less than 0.5 percent in each stress simulation. This indicates that this environmentally and biologically sensitive area may not be affected by 40 years of pumping, but small decreases in water availability can result in large impacts to the environmental system. This amount of change in water levels should be evaluated by biologists and hydrologists to determine its impact on Ash Meadows. The head-dependent boundaries along the southern edge of the model did not change in any of the stress simulations. This is because the natural flow direction in the area is generally north to south. Almost all of the additional water was derived from storage and the eastern, western, and northern constant-head boundaries provided the additional five to ten percent. This indicates that groundwater extracted from the rock matrix is the main source of water and some subsidence could occur as a result of increased pumping. The longterm sustainability of extracting so much water from the matrix should also be considered. If flow from other basins increased, possibly ones containing nuclear testing areas, contamination could be mobilized. Changes in the heads or the boundaries, possibly because of pumping of neighboring basins, would also change the water balance in the current simulations.

Since the hydraulic conductivity in the UGTA model, and therefore in the MVB model, decreases with increasing depth and wells were pumped dry at shallower depths, placing the screened interval of the hypothetical water-supply wells in model layers 8 and 9 , from 600 to $800 \mathrm{~m}$ above mean sea level, was optimal. Screened intervals of different lengths could also be modeled to test the effect on maximum achievable pumping rates. When siting and determining water permitting for future facilities on the MVB, detailed simulations should be run to find the optimum number and location of water-supply wells for the specific application.

The uncertainty in a model must always be considered when using predictions that are derived from it. The transient groundwater flow model of the MVB used steady-state and 
transient hydraulic conductivity, specific storage, and specific yield values from the most updated version of the DOE database, which is assumed to be reasonably accurate. Model parameters such as boundary placement and volumes of underflow are less well known. The model was verified with drawdown data from pumping wells, but there are few pumping wells within the large areal domain of the model. This model should be used as a guideline for determining water availability in the area. Higher or lower pumping rates are possible if different drawdown limitations or model assumptions are invoked.

\section{REFERENCES}

Anderson, M.P. and W.W. Woessner, 1992. Applied Groundwater Modeling, Simulation of Flow and Advective Transport. Academic Press, California.

Belcher, W.R., P.E. Elliott, and A.L. Geldon, 2001. Hydraulic-property Estimates for Use with a Transient Ground-water Flow Model of the Death Valley Regional Ground-water Flow System, Nevada and California. U.S. Geological Survey Water-Resources Investigations Report 01-4210.

Bright, D.A., S.A. Watkins, and B.A. Lisle, 2001. Analysis of Water Levels in the Frenchman Flat Area, Nevada Test Site. U.S. Geological Survey Water-Resources Investigations Report 00-4272.

Carroll, R.W.H., B. Giroux, G. Pohll, R.L. Hershey, C. Russell, and W. Howcroft, 2003. Numerical Simulation of Groundwater Withdrawal at the Nevada Test Site. Desert Research Institute, Publication No. 45163.

Fiero, B., 1986. Geology of the Great Basin. University of Nevada Press. Nevada.

Harbaugh, A.W., 1990. A Computer Program for Calculating Subregional Water Budgets Using Results from the U.S. Geological Survey Modular Three-dimensional Finitedifference Ground-water Flow Model. U.S. Geological Survey Open-File Report 90-392.

Harbaugh, J.W., E.R. Banta, M.C. Hill, and M.G. McDonald, 2000. MODFLOW-2000, The U.S. Geological Survey's Modular Groundwater Flow Model - User Guide to Modularization Concepts and the Groundwater Flow Process. U.S. Geological Survey Open-File Report 00-92.

Hardman, G., 1936. Precipitation map of Nevada showing areas of assumed equal rainfall. Prepared by Nevada Agricultural Experimental Station and Land Utilization Division Resettlement Administration.

IT Corporation, 1996. Groundwater Flow Model Documentation Package (Underground Test Area Subproject Phase I Data Analysis Task). Prepared for U.S. Department of Energy, Nevada Operations Office, Las Vegas, Nevada.

Maxey, G.B. and T.E. Eakin, 1949. Ground water in the White River Valley, White Pine, Nye and Lincoln counties, Nevada. State of Nevada, Office of the State Engineer, Water Resources Bulletin No. 8, 59 p.

McDonald, M.G. and A.W. Harbaugh, 1988. A Modular Three-dimensional Finite-difference Ground-water Flow Model. U.S. Geological Survey Techniques of Water-Resources Investigations, Book 6, Chapter A1, 586 p. 
Prickett, T.A., 1967. Designing pumped well characteristics into electric analog models. Groundwater 5(4):38-46.

Scott, B.R., T.J. Smales, F.E. Rush, and A.S. Van Denburgh, 1971. Water for Nevada, Nevada's Water Resources - State of Nevada Water Planning Report. Report No. 3. State of Nevada, Department of Natural Resources, Division of Water Resources.

Sweetkind, D.S, W.R. Belcher, C.C. Faunt, and C.J. Potter, 2004. Death Valley Regional Ground-water Flow System, Nevada and California-Hydrogeologic Framework and Transient Ground-water Flow Model. Chapter B, Geology and Hydrogeology. U.S. Geological Survey Scientific Investigations Report 2004-5205.

U.S. Department of Energy (DOE), 1997. Regional Groundwater Flow and Tritium Transport Modeling and Risk Assessment of the Underground Test Area, Nevada Test Site, Nevada. DOE/NV-477.

Waddell, R.K., J.H. Robison, and R.K. Blankennagel. 1984. Hydrology of Yucca Mountain and Vicinity, Nevada-California--Investigative Results Through Mid-1983. U.S. Geological Survey Water-Resources Investigations Report 84-4267. 


\section{DISTRIBUTION}

Bill Wilborn

Environmental Restoration Division

Nevada Site Office

National Nuclear Security Administration

U.S. Department of Energy

P.O. Box 98518

Las Vegas, NV 89193-8518

Ron Baugh

Bechtel Nevada

P.O. Box 98521

Las Vegas, NV 89193-8521

Dave Finnegan

Los Alamos National Laboratory

C-INC, M/S J514

Los Alamos, NM 87945

Ed Forness

Stockpile Stewardship Division

Nevada Site Office

National Nuclear Security Administration

U.S. Department of Energy

P.O. Box 98518

Las Vegas, NV 89193-8518

David Hudson

Bechtel Nevada

P.O. Box 98521, M/S NTS273

Las Vegas, NV 89193-8521

David Nienow, Contracting Office

Acquisition and Financial Assistance

Department

Office of Business Services

NNSA Albuquerque Office

P.O. Box 5400

Albuquerque, NM 87185-5400
Bruce Hurley

Hydrology Program Manager

Environment, Safety and Health Division

Nevada Site Office

National Nuclear Security Administration

U.S. Department of Energy

P.O. Box 98518

Las Vegas, NV 89193-8518

Kenneth Hoar, Director

Environment, Safety and Health Division

Nevada Site Office

National Nuclear Security Administration

U.S. Department of Energy

P.O. Box 98518

Las Vegas, NV 89193-8518

Marjory Jones

Division of Hydrologic Sciences

Desert Research Institute

2215 Raggio Parkway

Reno, NV 89512-1095

Annie Kersting

Lawrence Livermore National Laboratory

Isotope Sciences Division

L-213

P.O. Box 808

Livermore, CA 94550

Randy Laczniak

Water Resources Division

U.S. Geological Survey

160 N. Stephanie St.

Henderson, NV 89074-8829

Peter Sanders

Environmental Restoration Division

Nevada Site Office

National Nuclear Security Administration

U.S. Department of Energy

P.O. Box 98518

Las Vegas, NV 89193-8518 
David Shafer

Division of Hydrologic Sciences

Desert Research Institute

755 E. Flamingo Road

Las Vegas, NV 89119-7363

Bonnie Thompson

U.S. Geological Survey

160 N. Stephanie Street

Henderson, NV 89074

Don Van Etten

Environmental Technical Services

Bechtel Nevada

Bldg. 652/ Nevada Test Site

Mercury, NV 89023

Nevada State Library and Archives

State Publications

100 North Stewart Street

Carson City, NV 89701-4285

Archives

Getchell Library

University of Nevada, Reno

DeLaMare Library/262

University of Nevada, Reno

Document Section, Library

University of Nevada, Las Vegas

4505 Maryland Parkway

Las Vegas, NV 89154

Stoller-Navarro Joint Venture

P.O. Box 93838

Bldg. B-1, M/S 439

Las Vegas, NV 89193-3838

ATTN: Toni Miller, M/S 439

Library

Southern Nevada Science Center

Desert Research Institute

755 E. Flaming Road

Las Vegas, NV 89119-7363
Public Reading Facility

c/o Nuclear Testing Archive

Nevada Site Office

National Nuclear Security Administration

U.S. Department of Energy

P.O. Box 98521, M/S 400

Las Vegas, NV 89193-8521

Technical Library

Nevada Site Office

National Nuclear Security Administration

U.S. Department of Energy

P.O. Box 98518

Las Vegas, NV 89193-8518

Office of Scientific and Technical

Information

U.S. Department of Energy

P.O. Box 62

Oak Ridge, TN 37831-9939

(electronic copy) 